\title{
Co-evolution of technology and society: The transition in water supply and personal hygiene in the Netherlands (1850-1930)_a case study in multi-level perspective
}

Frank Geels*

Department of Technology Management, Eindhoven University, IPO 2.10, P.O. Box 513, $5600 \mathrm{MB}$ Eindhoven, The Netherlands

\begin{abstract}
This article deals with the systems level in Freeman and Perez's innovation typology (incremental, radical, system, techno-economic paradigm). Transitions at this level are understood as changes from one socio-technical system to another, involving co-evolution of technology and society. To understand these transitions, the article describes a multi-level perspective, based on insights from sociology of technology and evolutionary economics. This perspective is used to analyse a detailed historical case study, the transition from surface water to piped water and personal hygiene (1870 1930). By the middle of the 19th century, problems in the water supply regime grew worse, as expanding urban populations dumped their waste in canals and surface waters. Local conditions in some specific cities provided space for the first piped water systems in the 1850s. Problems in the water supply regime grew worse in the 1860s and 1870s, but public authorities in other cities did not embrace the new niche. Instead, they searched for solutions within the existing regime. Only after wider landscape developments in the 1880s and 1890s (economic, cultural, political) could the niche break through and trigger wider transformations. So external macro-developments played a crucial role in the take-off and diffusion phase of this transition. This transition is a good example of coevolution of technology and society, involving technological innovations, such as piped water infrastructure, soap, toilets, baths, as well as cultural, political, economic and behavioural changes. The case study illustrates how the multi-level perspective can be used to analyse how these changes
\end{abstract}

\footnotetext{
* Tel.: +3140247 54514; fax: +3140244 4602 .

E-mail address: f.w.geels@tm.tue.nl
}

0160-791X/\$ - see front matter (C) 2005 Elsevier Ltd. All rights reserved. 
influenced each other in a co-evolution process. The article thus fits in the growing literature on coevolution. While most literatures look at co-evolution between two or three aspects, this article develops a broader understanding of co-evolution.

(C) 2005 Elsevier Ltd. All rights reserved.

Keywords: System innovation; Co-evolution of technology and society; Hygiene and drinking water; Multi-level perspective

\section{Introduction}

Co-evolution is emerging as an important topic in a range of disciplines, e.g. evolutionary economics, innovation studies, industrial economics, and long-wave theories. It has always been an important theme in science and technology studies, with its emphasis on seamless webs, emerging linkages between heterogeneous elements and co-construction. Different aspects of co-evolution have been dealt with in the literature:

- Co-evolution between technology and users [1-5].

- Co-evolution between technology, industry structure and policy institutions [6-10].

- Co-evolution of science, technology and the market $[11,12]$.

- Co-evolution of science and technology [13-15].

- Co-evolution of technology and culture $[16,17]$.

Although co-evolution has been studied with regard to two or three aspects, a broader study of co-evolution is lacking. Such a study of co-evolution is especially needed to understand innovations at broader aggregation levels and longer time-scales, for instance the two highest levels of Freeman's and Perez's innovation typology. Freeman and Perez [18] distinguish four kinds of innovations. Incremental innovations occur more or less continuously in any industry to improve price and performance. Radical innovations are discontinuous events which are unevenly distributed over sectors and over time. Whenever they occur they are important as the potential springboard for the growth of new markets, and for the surges of new investment associated with booms. They often involve a combined product, process and organisational innovation. Changes of the technology system are far-reaching changes in technology, affecting several branches of the economy, as well as giving rise to entirely new sectors. They are based on a combination of radical and incremental innovations, together with organisational and managerial innovations affecting more than one or a few firms. Changes in the techno-economic paradigm (TEP) are so far-reaching in their effects that they have a major influence on the behaviour of the entire economy. The changes involved go beyond engineering trajectories for specific product or process technologies and affect the input cost structure and the conditions of production and distribution throughout the system. Changes in TEP are studied in longwave theories and radical innovations are the topic of many literatures in business studies and innovation studies. But changes in technology systems are under-addressed and have not been studied much. Such transitions from one technology system to another, so-called system innovations, are the topic of this article. 
To define systems, I build on the sociology of technology. Artefacts by themselves have no power, they do nothing. Only in association with human agency and social structures and organisations do artefacts fulfill functions. In real-life situations (e.g. organisations, houses, cities) we never encounter artefacts 'per se', but artefacts-in-context. For the analysis of functioning artefacts, it is the combination of 'the social' and 'the technical' that is the appropriate unit of analysis [19]. From the sociology of technology two basic notions of technology are important: (a) technology is heterogeneous, not just a material contraption; engineers know this, their work is 'heterogeneous engineering', (b) the functioning of technologies involves linkages between heterogeneous elements. Hughes [20] coined the metaphor of a 'seamless web' to indicate how physical artefacts, organisations (e.g. manufacturing firms, investment banks, research and development laboratories), natural resources, scientific elements (e.g. books, articles), legislative artefacts (e.g. laws) are combined in order to achieve functionalities. From these considerations it follows that societal functions such as transport, communication, water supply are fulfilled by a cluster of elements, which I understand as socio-technical systems [21]. Socio-technical systems consist of technology, regulation, user practices and markets, cultural meaning, infrastructure, maintenance networks, supply networks (see Fig. 1 for an example for land-based transportation).

The topic in this paper is: how do transitions from one socio-technical system to another (i.e. system innovations) come about? Technological substitution or radical technical innovation is not sufficient, because it involves only one element. System innovations are about changes in technology and in societal elements such as policy, culture, markets, etc. But how can we best conceptualise the co-evolution between technology and society? To answer that question, Section 2 describes a conceptual multi-level perspective (MLP). The MLP has been applied and illustrated with case studies that have a technology-focus, e.g. the transition from sailing ships to steamships [22], the transition from horse-drawn carriages to automobiles and from propeller-aircraft to turbojets [23]. These case studies have a 'traditional' artefact-focus. In contrast, Section 3 in this article analyses a different case study, the transition in drinking water (from pumps and surface water to piped water) and personal hygiene (from filth to frequent washing and bathing). This was a system innovation and not merely a radical innovation (in terms of Freeman and Perez's typology). Although technological innovations were important in this transition (e.g. piped

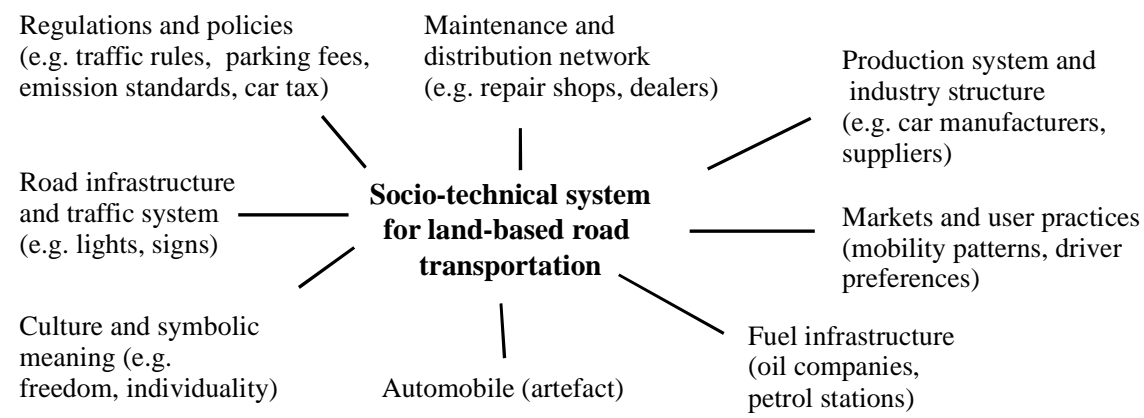

Fig. 1. Socio-technical system for modern car-based transportation. 
water infrastructure, soap, toilets, baths), changes in cultural meaning, behavioural patterns and policy were even more important. There were major changes in the meaning of cleanliness, a hygienic ideology emerged, new washing and bathing practices were developed and transmitted to the working-classes through a civilisation offensive. So the case study is a prime example of the co-evolution of technology and society. The case study deviates from mainstream case studies that place industrial technical products upfront and from there look at societal aspects. The story in Section 3 takes socio-technical systems as unit of analysis, placing technology in its societal context right from the start. The case study is also interesting, because it is about an everyday commodity (water) and behaviour that is now seen as 'normal' (washing, cleaning, personal care). The story will show that both aspects are achievements, realised in the late 19th and early 20th century. Section 4 distills some of the main features of co-evolution of technology and society in this transition, and the article ends in Section 5 with conclusions.

\section{The multi-level perspective on transitions and system innovations}

To understand major changes and transitions, the multi-level perspective (MLP) provides a useful framework [21-25]. The MLP distinguishes three analytical and heuristic levels. There are co-evolution dynamics at each of the three levels, but these usually remain relatively independent. Transitions take place when dynamics between the different levels become linked.

The micro-level is formed by technological niches, the locus for radical innovations. Niches act as 'incubation rooms' for radical novelties, shielding them from mainstream market selection [26]. Niches may have the form of small market niches, where selection criteria are very different from the existing regime or they may have the form of technological niches, where resources are provided by public subsidies or private strategic investments. These technological niches function as 'proto-markets' when market demand is not yet present. Technological niches are often played out in the form of experimental, pilot and demonstration projects, involving real-world users. The literature on strategic niche management distinguishes three important niche-internal processes [25,27-29]. The first process is learning. To create a working configuration, learning and co-construction processes are important on several dimensions (e.g. technology, user preferences, regulation, symbolic meaning, infrastructure, and production systems). The second process is the building of social networks and constituencies that support the new innovation and invest in its further development. The third process is the articulation of visions and expectations to provide an orientation towards the future and give direction to learning processes. The concept of technological niche has similarities to the notion of biological niche (i.e. a particular place in ecological food webs). A biological niche provides some kind of protection and resources (e.g. energy flows). These connotations are also important for technological niches, but additionally there is a socio-cognitive dimension from sociology of technology, looking at social networks and cognitive rules (e.g. problem agendas, search heuristics) that are both the outcome and context for learning processes. In niches, the social networks are usually small, and the cognitive rules 
unstable. There is little stability and much uncertainty, and actors work in different directions, exploring different trajectories.

The meso-level is formed by socio-technical regimes. This concept builds on Nelson and Winter's [30] notion of technological regimes, that refers to cognitive routines (e.g. search heuristics, exemplars) shared by engineers and designers in a technical community. Technological regimes create stability, because engineers in different firms search and work in similar directions. This results in technological trajectories at the sectoral level (i.e. incremental changes to refine existing technologies in particular directions). But socio-technical systems at the sectoral level are not only related to activities of engineers, but also to activities of other social groups (Fig. 2). To encompass these multiple social groups, the concept of technological regime is widened to socio-technical regime.

The activities of these social groups (re)produce and maintain the elements and linkages in socio-technical systems. The groups are interdependent and interacting with each other, leading to coordination and alignment. Socio-technical regimes account for dynamic stability of socio-technical systems, meaning that innovation still occurs but is of an incremental nature, leading to trajectories and path dependencies.

The macro-level is formed by the socio-technical landscape, which refers to aspects of the technology-exogenous environment (e.g. macro-economics, deep cultural patterns, macro-political developments). The metaphor 'landscape' is used because of the literal connotation of relative 'hardness' and to include the material aspect of society (e.g. road infrastructures, city structures, electricity grids). Landscapes are beyond the direct

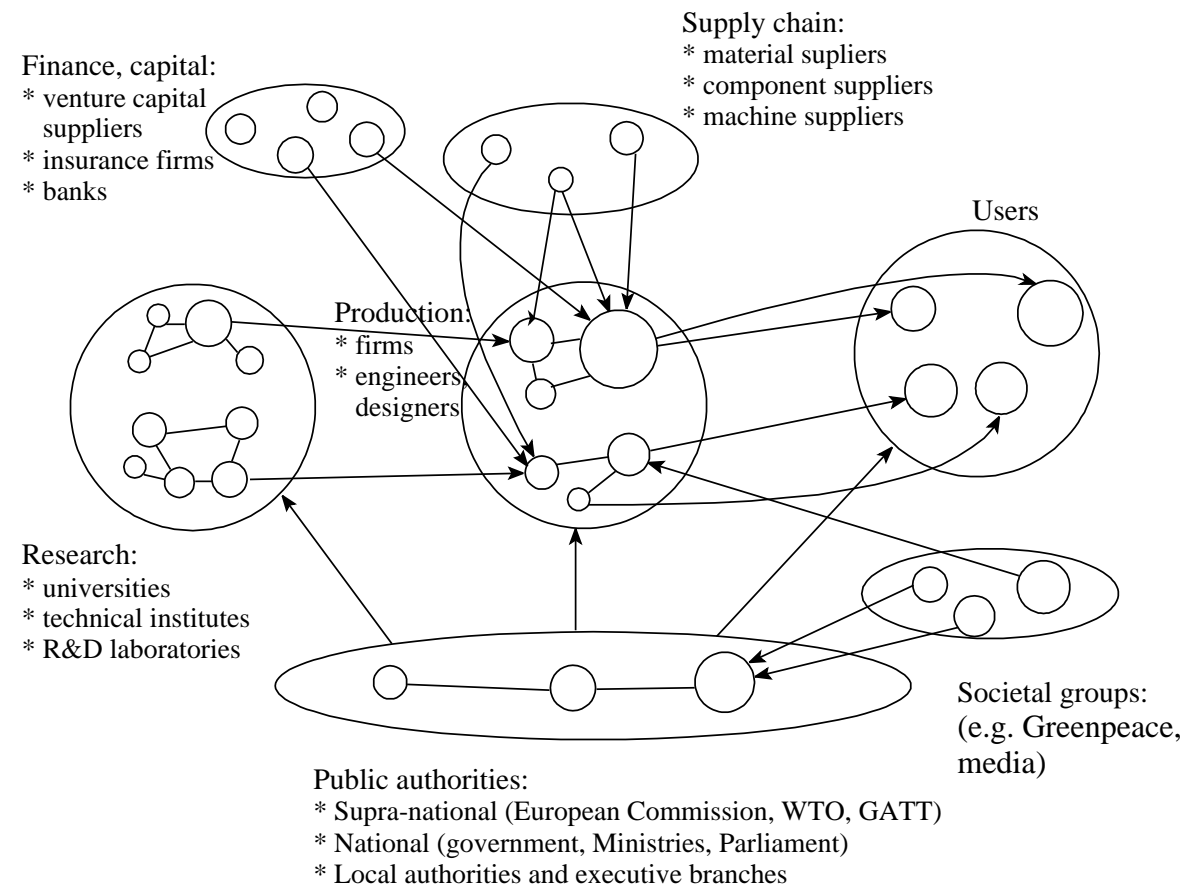

Fig. 2. Social groups that are part of socio-technical regime [22, p. 1260]. 


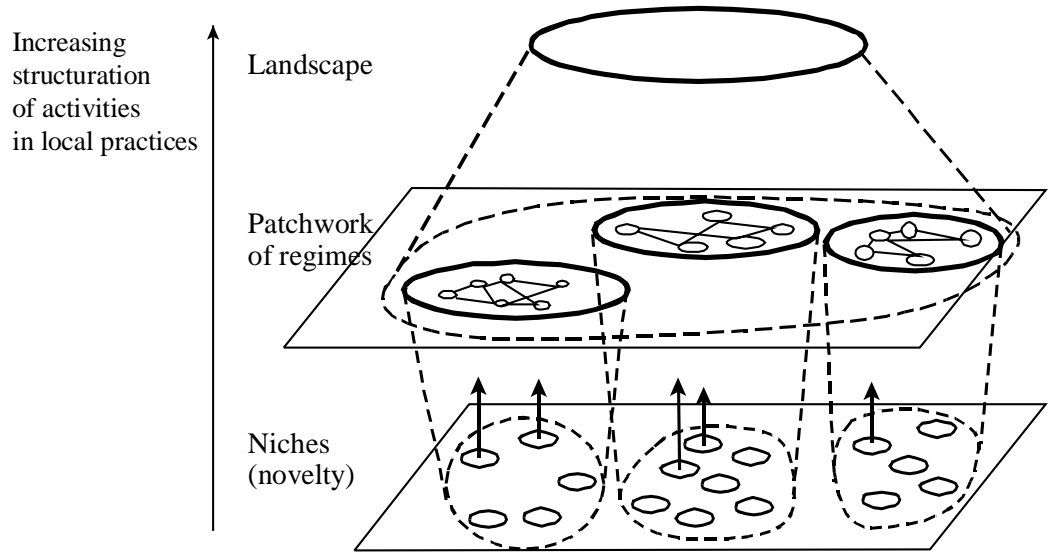

Fig. 3. Multiple levels as a nested hierarchy [22, p. 1261].

influence of actors, and cannot be changed at will. Changes at the landscape level usually take place slowly, in the order of decades.

The relationship among the three concepts can be understood as a nested hierarchy, meaning that regimes are embedded within landscapes and niches within regimes (see Fig. 3). The work in niches is often geared to the problems of existing regimes (hence the arrows in the figure). Actors support the niche hoping that novelties will eventually be used in the regime or even replace it. Niches are crucial for system innovations, because they provide the seeds for change.

The key point of the MLP is that system innovations come about through the interplay between dynamics at multiple levels. Several phases can be distinguished in transitions [31]. In the first phase, novelties emerge in niches in the context of existing regime and landscape developments. There is not yet a dominant design, and various technical forms may be competing with each other. Actors improvise, engage in experiments to work out the best design and find out what users want. The work in niches is geared to the problems of existing regimes. Actors support the niche, hoping that novelties will eventually be used in the regime or even replace it. This is not easy, because the existing regime is entrenched in many ways (e.g. institutionally, organisationally, economically, culturally). Radical novelties often have a mis-match with the existing regime [18] and do not easily break through.

In the second phase, the novelty is used in small market niches, which provide resources for technical specialisation. Gradually a dedicated community of engineers and producers emerges, directing their activities to further improvement of the new technology. As this community articulates new rules, the new technology develops a technical trajectory of its own. As users interact with the new technology and incorporate them into their user practices, they build up experience with it, and gradually explore new functionalities. This second phase results in a stabilisation of rules, e.g. a dominant design, articulation of user preferences. 
The third phase is characterised by a breakthrough of the new technology, wide diffusion and competition with the established regime. On the one hand, there are internal drivers for breakthrough. For instance, actors with interests may push for further expansion of the technology or price/performance dimensions gradually improve. On the other hand, breakthrough of the new technology depends on external circumstances that create 'windows of opportunity' (see Fig. 4). There may be changes at the landscape level, which put pressure on the regime. There may be technical problems and negative externalities in the regime, which cannot be met with the available technology. There may also be changing user preferences or stricter regulations, which create problems for the existing technology. The key point is the interaction between developments at multiple levels. As the new technology enters mainstream markets it enters a competitive relationship with the established regime.

In the fourth phase, the new technology replaces the old regime, which is accompanied by changes on wider dimensions of the socio-technical regime. This often happens in a gradual fashion, because the creation of a new socio-technical regime takes time. Furthermore, incumbents tend to stick to old technologies, because of vested interests and sunk investments. The new regime may eventually influence wider landscape developments.

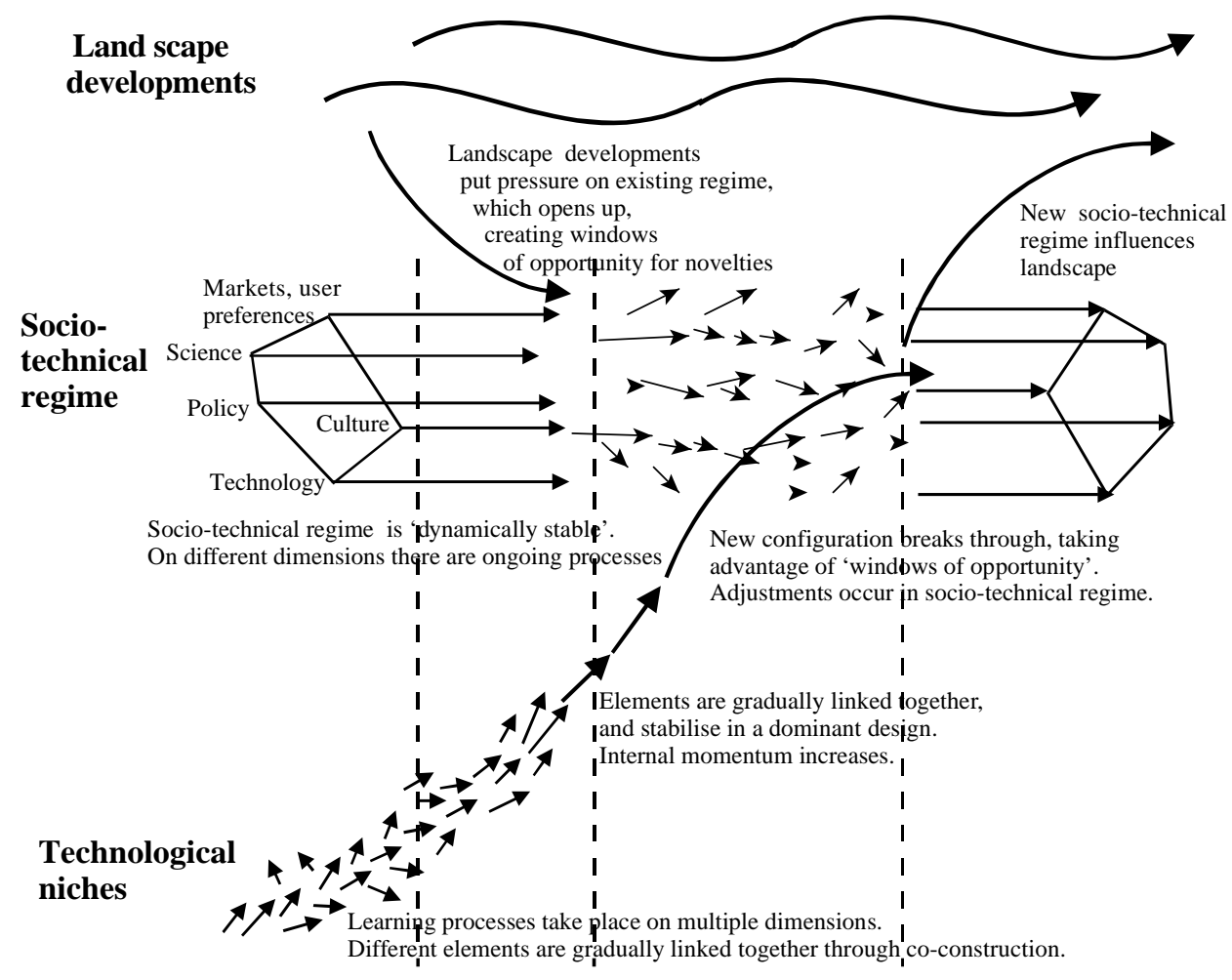

Fig. 4. A dynamic multi-level perspective on system innovations [22, p, 1263]. 
An important aspect of the multi-level perspective is to do away with simple causality in transitions. There is no simple 'cause' or driver. Instead, there are processes at multiple dimensions and levels simultaneously. System transformations come about when these processes link up and reinforce each other ('circular causality'). Another point is that innovations may start small and be used for particular local functions. Later, they can mushroom into something else and enable wider transformations. So transitions are characterised by non-linearity and uncertainty.

\section{Case study: the transition in water supply and personal hygiene in the Netherlands (1850-1930)}

The MLP will be used in this section to describe and analyse the transition in drinking water and personal hygiene. Data for this case study are based on secondary sources, in particular from the history of technology, urban history, social history and environmental history. Partial stories have been written about piped waterworks in particular cities, e.g. Amsterdam [32], Rotterdam [33], Maastricht [34] and Tilburg [35]. But an integrated story, which understands the emergence and diffusion of piped water in its cultural, societal and economic context, does not yet exist. Such an integrated story does not mean that piped water in different cities can be explained in exactly the same way. There was much local variety between cities in timing, depending on local environmental conditions (e.g., dependence on groundwater or surface water, degree of pollution) and the size of city. While the precise constellation of factors varies between cities, the same kind of elements are important. In that sense, an overall story can be written, which allows local contingencies and variety.

The transition in water supply and personal hygiene was part of the wider epidemiological transition, i.e. the drop in death rates between 1870 and 1930 (Fig. 5).

Fifty to seventy percent of the decrease in death rates can be attributed to the decrease in infectious diseases, both air-borne (lung tuberculosis, influenza, bronchitis, pneumonia, whooping cough, measles) and water-borne (dysentery, cholera, typhoid) [36].

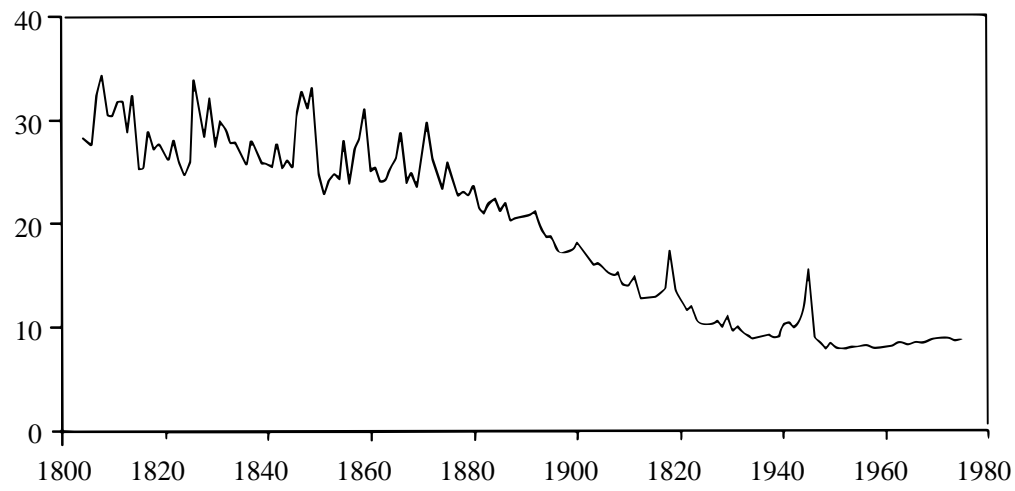

Fig. 5. Death rate in the Netherlands (number of deaths per 1000 person per year) [36, p. 10]. 
Three factors are seen as the main causes of this decrease: (1) more food, which improved people's resistance against disease, (2) hygienic improvements in waste disposal (sewer systems) and water supply (piped water), and (3) improvements in housing, which limited the spread of air-borne disease. The case study in this article is thus part of the second factor. The transition is divided into several periods, for which dynamics at landscape, regime and niche level will be described.

\subsection{Predevelopment: filthy conditions before 1850}

\subsubsection{Landscape developments}

The macro-political culture in the first half of the 19th century was characterised by bourgeois liberalism. Intervention from public authorities in society was limited. People had to take care of themselves, and health care and hygiene had low political priority. The right to vote was limited to those men who paid more than a certain amount of tax (census). Political inequality was seen as normal in the class society. There was a small upper class formed by the bourgeoisie and nobility, and a large class of workers and peasants, living in poor conditions. The lower classes were humble, obedient and respectful towards the upper classes. The upper classes were condescending and patronising towards the lower classes. They felt that working class people had no discipline, no rational control, and indulged their instincts. Being poor and sick was blamed on individual characteristics. Economically, the Netherlands did not do well in this period. While industrialisation took off in countries like Britain and Belgium, the economy of the Netherlands remained agricultural, complemented by some trade and finance [37]. There were high government debts at the national level, due to low tax income and a failed military expedition against Belgium in the 1830 s.

\subsubsection{Regime developments in drinking water, medicine and personal hygiene}

In the first half of the 19th century, there were three main sources for drinking water: (1) surface water (canals, rivers), (2) groundwater, and (3) rainwater. The availability of these sources varied between cities, depending on the geo-hydrological structure. The sand dunes in the west of the country had clean underground sweet water. The sand layers acted as filters, because the sand grains were covered with bacteria, algae and worms that removed micro-organisms, germs and oxidized organic matter. The polders behind the dunes, where many large cities lie, consist of thick clay, where no groundwater basins are formed. Salt water from the sea creeps up behind the dunes, sometimes causing surface waters to become brackish. The hills in the middle of the country (around Utrecht and Veluwe area) again provide sand filters, resulting in sweet ground water. In the North-East (Drente) and South the peat fields absorb around 60-70\% of rainwater, limiting the amount of rainwater that forms groundwater. In hilly areas in the far South (Limburg) groundwater can only be found at great depths.

The three water sources each had their advantages and problems. Surface waters often suffered from organic pollution. Because there were no sewer systems, most people and animals dumped their excrements and urine on streets and in surface waters. Only the middle-classes had privies and cesspools. In rivers and lakes there was sufficient water circulation to remove or dilute the waste. But urban canals and ditches had much less 
circulation. In stagnant waters, pollution with organic matter was a problem that created much stench, especially in summertime. These so-called miasmas were feared, because medical theories saw them as important cause of diseases. Poor people commonly drank from surface waters. It was free of charge and easy to find. But the polluted water was also a major cause of diseases, although this was not known at the time.

Groundwater could be obtained in some cities (e.g. Utrecht, The Hague) by sinking wells or constructing pumps. Many middle-class people constructed private pumps to have access to clean water. City governments also constructed public pumps, but were not very active in maintenance. Most public wells and pumps functioned moderately, providing clean water only in the morning and becoming turbid as the day progressed. Shallow ground water was usually collected with hand pumps, but it was frequently contaminated, by leaking cesspools ${ }^{1}$ or because polluted surface waters sank through. Deeper groundwater was often cleaner, but more difficult to reach. American Norton pumps (around 1860) made it easier to reach these deeper water levels. But deep groundwater often contained high concentrations of iron, giving the water an inky flavour [38]. Groundwater was problematic and brackish in many cities in the polder areas such as Rotterdam, Amsterdam, Goes, Delft, Leiden, and Purmerend.

Rainwater could be collected from the roofs of buildings or specially paved areas. But the construction of large water basins was expensive and only used by wealthy people. Poor people collected water in barrels, but rainwater quantities were not enough for survival. And the variability in rainfall could lead to water scarcities in dry times.

The medical regime was still in its infancy in the first half of the 19th century, with limited understanding of disease and limited possibilities for treatment. The dominant understanding was that diseases were caused by external circumstances (e.g. cosmic influences, position of the stars, atmospheric conditions, bad air, and bad soil). Disease was seen as an entity out there, which could invade human bodies [39, p. 24]. A major shock to the medical profession came from a new disease, cholera, which struck the Netherlands in major epidemics in 1832 and 1848 [40, p. 85]. The disease, which, as we now know, spreads through surface water polluted with feces from cholera patients, sprang up at multiple places simultaneously, without direct contact between people. Hence, doctors believed that environmental factors were important. They became particularly fearful of air contaminated with harmful vapours, so-called miasmas, which could arise from decaying organic matter. Hence, the organic pollution of urban canals was seen as dangerous. The response from city governments was to improve the water circulation in canals so that organic waste would be flushed away. But no substantial action was taken, because of lack of money, lack of understanding, lack of will and indifference. Health was seen as an individual responsibility, not as a responsibly of public authorities [41, p. 82].

Personal care and hygiene were hardly developed in the 19th century. Most people did not or seldom wash themselves, and public life was permeated with stench [42]. Bathing was not a popular activity in the early 19th century. Baths were associated with vice and dissoluteness, because they could be found in luxurious brothels, wealthy hotels or Turkish

\footnotetext{
${ }^{1}$ Because emptying cesspools was dirty work, it was common practice that residents removed the bottom bricks of cesspools, allowing contents to leak into the soil, thus reducing the need for frequent emptying.
} 
baths. Furthermore, many 19th century doctors were suspicious about frequent bathing. Once a month was acceptable, once a week was risky. Lying in water was seen to weaken the body, nerves, and muscles. For young girls too much bathing could affect the brain, possibly making them mentally deficient [34, p. 87]. It was also commonly believed that a layer of dirt protected against disease.

\subsubsection{Niche developments in personal hygiene}

Polders in the West of the Netherlands suffered most problems in their water supply, because of brackish groundwater and large, thirsty urban populations. Especially, Amsterdam continually struggled with quantity problems in drinking water, because groundwater was often brackish and canals were increasingly polluted. This created a window of opportunity for a novel way of water supply, the import of drinking water on special water ships from elsewhere [32, p. 83]. Already in 1786 Amsterdam's city government created the Fresh Water Society, granting concessions to a professional group of water importers. City regulations specified source and quality norms of the water, which were checked by inspectors. Residents could buy the imported water per bucket. The Fresh Water Society thrived until around 1860. But water import never solved the quantity problem, since it accounted, at most, for about $8 \%$ of drinking water needs [38, p. 119].

With regard to personal hygiene, demand from the upper classes formed market niches for the development of innovations such as soap and toothbrushes. Soap already existed in Roman times, made by mixing particular salts with fatty acids. During the later Medieval Times bathing fell out of favour, limiting the use of soap. People of the Renaissance did not wash their body, but covered it with heavy scents and perfumes. But soap continued to be used for washing clothes. In 1791 Nicholas Leblanc, a French chemist, patented a process for making soda ash (or sodium carbonate) from common salt. Soda ash combined well with fat to form hard soap. The business of soap making became easier and cheaper [43]. Still, soap was expensive during the first half of the 19th century. Because it was categorised as a luxury product for the upper classes, hefty taxes were imposed that increased its price. Furthermore, demand for soap remained low, because there was no established bathing routine. People also paid little attention to cleaning their teeth. Toothpicks or fingers were most commonly used. In the early 19th century, the toothbrush gained popularity with the bourgeoisie, as the cosmetic importance of clean teeth and fresh breath increased [44]. But toothbrushes remained expensive, because they were made of bone and pig hair.

\subsection{Articulation of health and hygiene problems (1850-1880)}

\subsubsection{Landscape developments}

An important landscape development was the new constitution of 1848, which widened the census and enabled tax-paying citizens to be candidates for Parliament or city council. In 1850 around $10.7 \%$ of Dutch men above 23 years could vote for Parliament, and $18 \%$ for local city councils [45, p. 340]. Liberalism was at the height of its power. The intervention from public authorities in society was limited, leaving much space for private initiative. Health care and poverty had low priority. Liberal ideology maintained that wealth would trickle down to the rest of society and solve poverty problems. 
On the macro-economic dimension, productivity slowly increased in the 1850 s and 1860 s, but manufacturing and industry did not yet take off [37]. Large farms increasingly took over smaller farms, uprooting many peasants. These peasants went to the city to find work, contributing to urbanisation. National tax incomes remained low in this period, limiting the possibilities for state intervention. This gave local city authorities much freedom and autonomy, something that was formally acknowledged in the Municipal Law (1851). This law made city governments responsible for public works, public health and hygiene, and social order. City governments preferred to keep their involvement in public life low, to keep taxes low for their voters. Self-organisation was a social development from citizens, which led to an increase in the number of clubs and associations after 1850 [45, p. 378]. Examples are the Society for Benefit of Common Good, the Association of Public Lectures and the Society for the Working Class. These associations organised debates, lectures and discussions to inform people about new insights on a range of topics. This period also saw the emergence of the first labour unions, e.g. the Society for the Benefit of Workers (1851) and the Workmen Society (1855). These labour unions aimed mainly at entertainment and public education, not (yet) politics. The increase in the number of clubs and associations provided new forums for public debate. There was also an increase in media, e.g. the number of large newspapers increased from 5 in 1865 to 9 in 1870 [45, p. 384-5]. These media gave more publicity to political decisions, which had previously been made in closed circles.

In the 1870 s and 1880 s, the economic situation in the Netherlands began to improve, as industrialisation gathered speed [37]. The increasing use of steam and machine tools raised productivity, drawing more labourers from rural areas to large cities. The enhanced urbanisation created serious housing problems, and many people lived in crowded, damp and unhygienic conditions. Another landscape development was that labourers became more vocal about their conditions, since industrialisation created more demand for workers and improved their relative power. Bargaining power of workers was also increased because they increasingly organised themselves in labour unions. A general labour union was created in 1871, the General Dutch Union for Workmen (ANWV).

\subsubsection{Regime developments in medicine and drinking water}

In this period, medical science began to link bad hygienic conditions with infectious disease, especially through the work of a few 'hygienist' doctors operating outside the mainstream medical community. In the 1840 s and 1850 s, these hygienist doctors developed medical statistics as a means to describe and analyse health problems. They could build on insights developed in the 'sanitarian movement' in France and England [46]. Through data-collection, they mapped the distribution of diseases and death rates over different cities and neighbourhoods. The differences could then be correlated to hygienic variables, such as waste-disposal, insufficient street cleaning, canals with still water and decaying organic material, crowded houses [39, p. 38]. Although the correlations did not explain underlying causes of diseases, the statistical method was a powerful means to describe health problems. It placed the relationship between hygiene and disease on the agenda.

After the second cholera epidemic in 1848, debates about the origin of diseases heated up. Collected data suggested that areas with similar environmental conditions were 
affected differently by cholera, suggesting at least some transmission between people. In the 1850s, a new theory emerged that suggested that the origin of the disease was caused by environmental conditions, in particular miasmas. But once the disease had emerged, its transmission could occur from person to person [46, p. 132]. With this combined miasmatic-contagious hypothesis, doctors began to link cholera with sanitary conditions. But there were still many uncertainties about the exact mechanisms of origin and transmission. In Britain, John Snow, a hygienist doctor, proposed an alternative theory about cholera in 1849. He argued that the disease was spread through drinking water contaminated with feces from cholera patients. His evidence was the Broad Street pump in London. He found that many people in the area of this pump suffered from cholera. When the pump was closed, cholera disappeared. But this theory had little effect on the mainstream Dutch medical community, because it did not fit with their miasmaticcontagious paradigm. Nevertheless, most doctors began to see local environmental conditions (soil, air) as important variables in the emergence and spread of cholera. It was also accepted that feces from cholera patients played a role, as well as groundwater. But the exact causal mechanisms were still unclear.

The issues of hygiene and health were discussed in city councils, newspapers, clubs and associations. But city governments did not take any substantial action, because health was still seen as a private responsibility, and because they were reluctant to spend money on expensive infrastructural works. Cities in other countries began to implement sewer systems, e.g. Hamburg (1843), London (1859), Paris (1871), and Berlin (1873). Dutch cities continued to rely on waste dumping in canals, cesspools, and collection of feces in barrels. Dutch sewer systems were implemented much later, e.g. The Hague (1893), Amsterdam (1913).

As populations of large cities grew, problems with drinking water increased. Large cities in the west of the country experienced quantitative problems to get enough drinking water for the growing population (especially Amsterdam). Another problem was deterioration of the quality of drinking water. No comprehensive waste-collection solutions (e.g. sewers) were implemented, and people continued to dump waste and excrements in the water. Hence, urban canals were increasingly polluted, and hygienist doctors warned that drinking this water was related to the spread of infectious diseases. Even shallow groundwater could be infected, when surface water seeped through. The cholera epidemic of 1866/7 helped to underline the danger of polluted drinking water, e.g. through representations in public media (Fig. 6).

Following the cholera epidemic, a National Drinking Water Commission was set up. The commission concluded that drinking water was generally of low quality. An investigation of pumps in Utrecht, for instance, showed that only $27 \%$ of private wells and $14 \%$ of public wells provided good water [40, p. 130]. The commission claimed that polluted drinking water played a role in the diffusion of cholera, although exact causal mechanisms remained unknown. The commission recommended that public authorities should play a more active role in feces collection and the provision of clean drinking water [47, p. 69]. Although the commission's report received much publicity and was widely discussed, public authorities were slow to act. In 1874, the Minister of the Interior, Van de Coppello, expressed the hope that a new Ministry of Public Health would soon be created. 


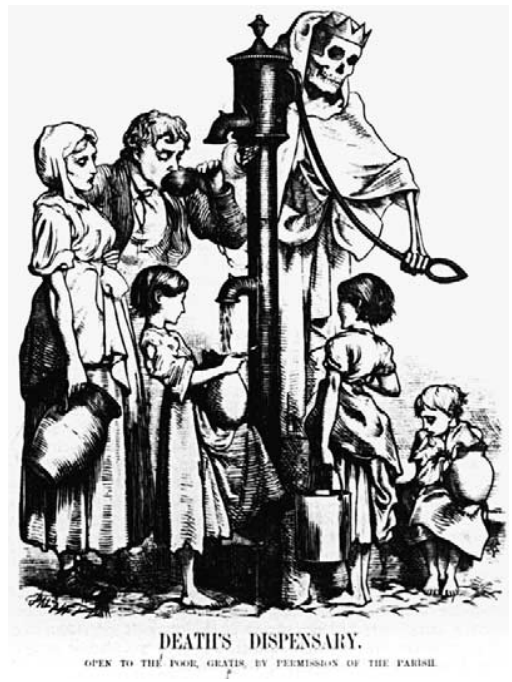

Fig. 6. American cartoon from 1866: cholera hands out to the poor [40, p. 244].

But no action followed. Despite public debates about health and hygiene, no national health policy was developed.

With regard to water supply, city governments implemented incremental solutions within the existing regime. One solution was to improve water circulation in urban canals, using steam engines to pump in fresh water and remove polluted water. Another solution, depending on geo-hydrological structures, was to increase the number of public wells, especially American Norton pumps that could reach deep groundwater. But many people rejected deep groundwater, because it had an ink-like taste. Residents of poor neighbourhoods in Utrecht continued to drink from canals in 1867, although they were warned of negative effects, and although four deepwater pumps were available nearby [38].

\subsubsection{Niche developments}

Piped water systems emerged as an alternative water supply option in two cities: Amsterdam (1853) and Den Helder (1856). This niche depended on special local conditions in both cities. Den Helder was a naval town from where many ships departed. Piped water was implemented not for health reasons, but for economic reasons, selling clean water to departing ships. Amsterdam's special condition was the scarcity of good drinking water. There had been many plans and proposals in the first half of the 19th century to create piped water systems in Amsterdam. They failed not because of technical problems, but because of financial difficulties. Much money was needed for all components of piped water systems. Land had to be bought or concessions needed to be acquired for water-winning areas, deep wells had to be drilled, steam engines and water towers were needed to create sufficient pressure, and a piped infrastructure had to be created to transport the water from the water-winning area to cities. Because Amsterdam's city government was unwilling to finance such systems, innovators had to attract private 
capital, which proved to be difficult. Several innovators acquired municipal concessions for their plans (e.g. Eedberg in the late 1830s, Brade and Bake in 1840), but they failed to secure interest from financiers. Finally, in 1851, the engineer Vaillant and the writer Van Lennep were able to secure funding from British investors, who already had some experience with piped water systems in their own country. The Dunewater Pipeline Company dug wells in the dunes, and transported water through a 20-kilometer pipeline to Amsterdam. The main motive was to make money, not the improvement of public health. In Amsterdam piped water was distributed in two ways. The first way was to sell water per bucket via taps connected to a main waterpipe (see Fig. 7). This distribution method built upon the existing practice where people had to collect water themselves at wells and fountains. By 1866, there were 56 taps distributed over the city.

The second distribution method was through private connections at home. Households could subscribe to the water company, and pay a fixed price, depending on the number of rooms. A house with one room paid 7 guilders per year, two rooms paid 11 guilders, three rooms 15 guilders, four rooms 18 guilders [32, p. 76]. Only rich people could afford private connections. After a hesitant start, the sale of piped water grew rapidly. The Fresh Water Society, which operated special water ships, lobbied the city government for protection, but this had no effect. By 1860, it was clear that water ships could not compete with piped water.

Two decades later, in the 1870s, Rotterdam also implemented piped water. Rotterdam's system was a side effect of its canal-flush waste-disposal system. In this system, canals functioned as open sewers, carrying off rainwater, wastewater, and human excrements. Water from the river Meusse was used to flush canals twice a day, making use of the tide. The system was finished in 1865 , but experience showed that water circulation was too low during low tide. Hence, the city government created water reservoirs in 1874 to provide flushing during low tide. As a side-product, the Municipal Drinking Water Agency

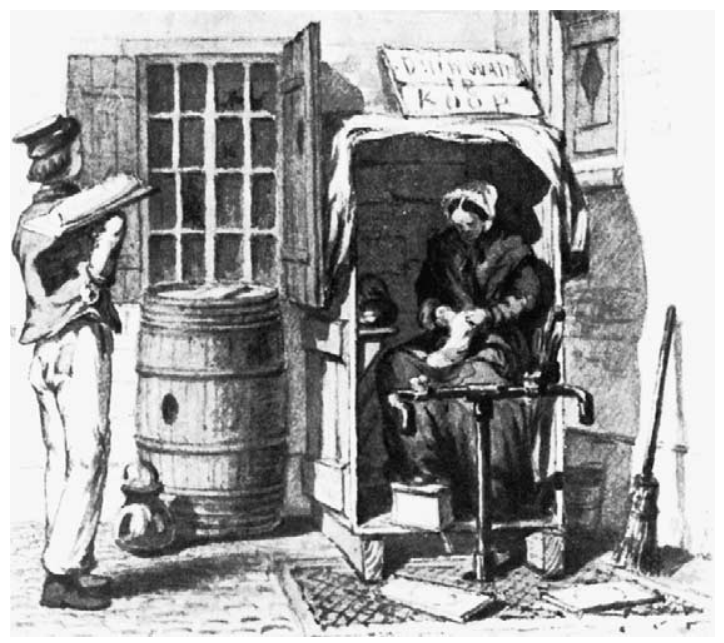

Fig. 7. Sale of piped water via taps [32, p. 93]. 
sold water from these reservoirs as drinking water. The aim was not to stimulate hygiene or public health, but to regain some of the cost of the canal-flush system [33, p. 40].

A cultural innovation in this period was that the bourgeoisie developed new etiquettes and behavioural patterns with regard to cleanliness [48]. In the class society, social distinction between the classes was crucially important. The concepts of 'dirty' and 'clean' came to play a central role in this process, dividing the urban population into 'high' and 'low', into 'elite' and 'common people'. To emphasise the social distinction between themselves and the working classes, the middle-classes placed more emphasis on cleanliness, suppression of body smells, self-control, and suppression of emotions. The ambition was to ban bodily odours from public space [42]. Filth and stench were increasingly associated with paupers, with everything that was 'low' and 'uncivilized' [49]. Lower classes came to be seen as the 'unwashed' [50, p. 142-3]. Washing, scrubbing and flushing became ways to emphasise social distinction. These notions of cleanliness became more important not because of health considerations but because of social distinction and moral connotations. For the bourgeoisie, exterior cleanliness represented an inner purity, associated with notions such as virtuousness, sincerity, sense of duty and respectability.

As the bourgeoisie developed more interest in personal hygiene, a small market niche emerged for hygienic innovations such as water closets, showers, and baths. These objects had their own water reservoirs, which were filled by servants carrying buckets of water. The bourgeoisie developed new sensitivities about relieving themselves. The sounds and smells were increasingly felt to be embarrassing. Water closets were popular because they removed excrements without many bad smells [51, p. 53].

Bathing habits of the upper classes also changed, signaled by the appearance of public bathing houses, e.g. in Maastricht in 1858 [34, p. 75]. Men and women bathed strictly separately to avoid embarrassment. Bathing in the sea also became more popular, as indicated by the appearance of luxurious seaside hotels in the 1870s [51, p. 56]. As bathing came back into fashion, the consumption of soap increased and soap making turned into a massive industry [43]. Solvay's ammonia process (1861) reduced the cost of obtaining this alkali, and increased both the quality and quantity of the soda ash available for manufacturing soap.

\subsection{Take-off of piped water systems (1880-1900)}

\subsubsection{Landscape developments}

The Dutch economy grew rapidly between 1890 and 1914, as industrialisation took off [37]. National income rose $120 \%$ in the 50 years between 1860 and 1910. Economic growth led to higher tax incomes for cities and state, providing more financial means for intervention. An important cultural change was increased sensitivity about the condition of working classes and the 'social issue'. Labour unions became more vocal about working class living conditions. Especially, the socialist labour union, set up in 1880, drew attention to problems of poverty, socio-economic inequality and the class struggle. Awareness of the social issue was also stimulated by several Parliamentary Inquiries (e.g. in 1887 about working conditions in factories). An important macro-political change was the emergence of new political parties. By the mid-1880s, members of the Socialist party 
marched through major cities demanding a general right to vote, creating a tense political atmosphere, with the threat of revolution in the background. Two other new parties were the Protestants and Catholics. The new parties criticised the liberal laissez-faire ideology and placed poverty and socio-political inequality high on the agenda. Another development in the 1890s was a change in the perceived role of public authorities. It became more accepted that city governments had a task and public responsibility to improve urban life for all residents. More active intervention began at the local level in cities [50]. This change was related to cultural and political concern about the social issue and was enabled by higher tax incomes. Another political development was further democratisation. In 1887, the census was lowered and the right to vote widened. As a result, in the Parliamentary elections of 1890 around $28.6 \%$ of the male population could vote [45, p. 407]. In 1896, the attributive right to vote was installed. And in 1917 the general right to vote was extended to all men, and in 1919 to all women.

\subsubsection{Regime developments in medicine, drinking water and personal hygiene}

In the medical community, the basis of a new theory about the origin of disease emerged with the work of Pasteur, who showed between 1860 and 1865 that the atmosphere contained micro-organisms. There was uncertainty about the mechanisms through which such micro-organisms might cause specific diseases. By $1880 \mathrm{Cohn}$ and Koch had developed colouring methods that helped visualise bacteria and facilitated the identification of different kinds of bacteria. In 1880, Pasteur identified two bacteria responsible for particular diseases (the streptococcus, and staphylococcus). And in 1883 Koch found the bacteria that caused tuberculosis and cholera. The new micro-organism theory was not immediately accepted and some Dutch doctors continued to believe in miasma- and soil-based theories [46, p. 157]. But the different theories agreed about the importance of unhygienic conditions in the spread of disease.

In this period, public attention for hygiene and disease increased. Population growth and urbanisation further exacerbated waste-related problems and stench. Together with increased sensitivity about the social issue and advances in medical science, these developments resulted in a widespread feeling that hygienic conditions had to be improved. Nevertheless, hygiene was not a crucial driver for the take-off of piped water systems in this period.

In this period, poor people and the working classes continued to use surface water, pumps and rain barrels as their main source of drinking water, because they were free of charge. Because pollution of surface water remained a problem, some city governments installed more public pumps. But other cities wanted to reduce their traditional responsibilities for water provision. The city government of Maastricht, for instance, wanted to encourage the use of private water pumps in the 1870s and piped water in the 1890s. To that end they deliberately neglected the maintenance of public pumps [34, p. 93]. This led to a gradual decrease in the number of public pumps in Maastricht (Table 1).

Although large parts of the population continued to depend on traditional water supply sources, attention of most actors in the drinking water regime shifted towards piped water systems. The market niche for piped water experienced rapid expansion in the 1880 s and 1890s (see Table 2). 
Table 1

Public pumps in Maastricht [34, p. 93-4]

\begin{tabular}{lll}
\hline & Number of public pumps in Maastricht & One public pump per number of residents \\
\hline 1800 & 62 & $240-250$ \\
1851 & 125 & 189 \\
1861 & 96 & 278 \\
1885 & 59 & 510 \\
1903 & 6 & $>5000$ \\
\hline
\end{tabular}

Piped water was still a niche in the 1870 s and 1880 s, because many rules had not yet crystallised, and there were many uncertainties on important dimensions such as:

- Market. Would there be sufficient market demand? Many rich people already had their own private pumps or rainwater basins. Would they be willing to pay for piped water subscriptions? What would be the right price for water? How would demand develop over time? Market considerations were crucial for private water companies, aiming to make money. But also city governments would not build piped water systems, unless there was sufficient demand from rich people to make them economically viable. So the size of cities and the size of middle-classes with buying power were important variables that influenced the timing of piped water implementation. There was a strong correlation between the size of cities and the year that piped water was implemented [52, p. 81].

- Finance. Initially city governments did not see it as a public task to provide clean drinking water, leaving it to private initiative. Private investors and entrepreneurs mainly looked at profit opportunities. Next to the expected market size, conditions of acquiring finance were important. City governments frequently agreed to concessions that reduced the financial risks in the first operating years (e.g. paying compensations

Table 2

Year of implementation of waterworks in Dutch cities [38, p. 5]

\begin{tabular}{llll}
\hline Amsterdam (Haarlem water) & 1853 & $\begin{array}{l}\text { Delft, Amsterdam (Vecht water), } \\
\text { Niewer Amstel, Kampen, } \\
\text { Oud-Bijsterland, Leeuwarden }\end{array}$ & 1888 \\
Den Helder & 1856 & Venlo, Zutphen & 1889 \\
Rotterdam & 1874 & Tiel, Amersfoort & 1890 \\
The Hague & 1874 & Maassluis & 1891 \\
Leiden, Katwijk & 1878 & Enschede, Almelo, Middelburg & 1892 \\
Nijmegen & 1879 & Zwolle, Almelo, Deventer & 1893 \\
Groningen & 1881 & Breda, Apeldoorn, Meppel, Delden & 1894 \\
Dordrecht & 1882 & Tilburg & 1895 \\
Delfshaven, Utrecht, De Bilt & 1883 & Hellevoetsluis, Harderwijk, Zeist & 1896 \\
Vlissingen, Arnhem, Baarn, Soest, & 1885 & Hengelo, Assen & 1897 \\
Alkmaar, Vlaardingen & 1886 & Nijkerk, Rheden, Zwijndrecht & 1898 \\
Zaanstreek, Gorinchem, Schiedam, & & & 1899 \\
Hilversum & 1887 & Bergen op Zoom, Helmond, & \\
Sliedrecht, 's Hertogenbosch, & & Roermond & \\
Roosendaal, Maastricht & & &
\end{tabular}


if sales were below a certain amount) [34, p. 43]. Nevertheless, entrepreneurs often had difficulty in finding investors. Water was initially a difficult product, because many people could not imagine that profits could be made with an ordinary product such as water [47, p. 75]. Dutch banks and investors often took a wait-and-see attitude.

- Water supplies. What was the best source of drinking water: surface water or groundwater? Some cities used groundwater from the dunes (Haarlem, Amsterdam, The Hague), others from rivers (Rotterdam, Maastricht) or from small lakes (Tilburg). How large and reliable were these sources? What would be the effect of drinking water on groundwater levels? Would rivers become more contaminated in the future?

- Quality of piped water and purification. Dune water was relatively pure, but surface waters could be contaminated. Should the water be cleaned and, if so, how?

- Organisational form. Early water companies in Amsterdam and Den Helder were private initiatives. City governments were initially hesitant to get involved. But since private initiative could be slow and hesitant, city authorities considered constructing waterworks themselves. The city of Rotterdam had shown that this was possible. Gradually, the number of public initiatives increased (Fig. 8). So both private and public options co-existed, creating uncertainty about the best organisational form.

The creation of a piped infrastructure usually was a stepwise process. First, a main pipe was created from the water-winning area to the city. Here it was further distributed in two ways, either through a network of smaller pipes to private households with subscriptions, or through taps connected to the main pipes where people could buy water per bucket. In subsequent years, the network of smaller pipes to private households was gradually

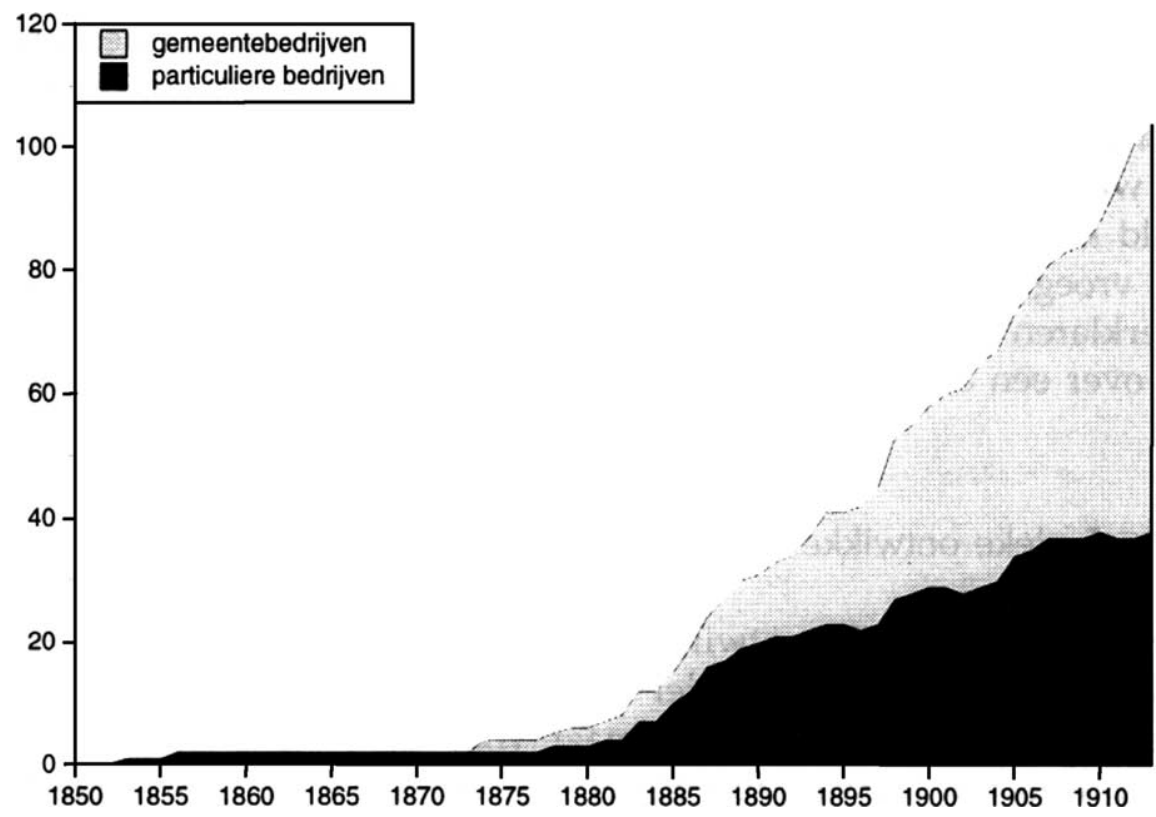

Fig. 8. Number of municipal (grey) and private (black) water companies in the Netherlands [53, p. 195]. 
expanded, as people became richer. In the early years, only a limited network of water distribution pipes was created, mainly in rich neighborhoods. People living hundreds of meters from this main network could not immediately be connected, because it was very expensive to break up roads and implement new pipes. Only if there was (an expectation of) sufficient demand, were networks expanded. These problems were less pressing when new houses and neighborhoods were created, since this did not require breaking up existing infrastructures [51, p. 147]. The growth of cities and the creation of new neighborhoods provided good growth markets for piped water systems.

Different social groups had different objectives and motivations regarding piped water. For private entrepreneurs, the main objective was to make money. They would construct piped waterworks if there were sufficient demand from people with buying power. City governments had locally different reasons to stimulate piped waterworks. In some cities, such as Rotterdam, piped water could piggyback on the creation of a canal-flush sewer system. Drinking water was a by-product of the canal-flush sewer system, to help pay for its costs. A second reason to construct piped waterworks could be to raise the city's prestige. The city of Maastricht, for instance, worried about middle-classes moving out, which was a threat to the tax base. To improve the city's prestige, Maastricht implemented piped waterworks [34, p. 39]. Third, for cities that suffered from quantity problems (e.g. Amsterdam), piped water was an additional means of providing drinking water. A fourth reason was to improve hygiene and public health, but this was seldom the deciding factor. The first users of piped water were not the poor working classes who might have experienced real health benefits from clean drinking water, but rich people, who usually already had other means to get clean water (e.g. private pumps, rainwater basins, buying of imported water).

Different kinds of users (rich citizens, industrial firms, municipal agencies) had different motivations to pay for piped water. An important reason for rich people was increased comfort. Piped water offered a new functionality in water supply. It was no longer necessary to go outside (to a pump, river or well), but one could simply turn the tap. Secondly, piped water was a means to show status and social distinction. Thirdly, quantitative problems could create demand for fresh and clean drinking water. In Amsterdam and The Hague rich citizens were willing to pay for clean dune water, because it was better than water from local sources. A fourth reason was the linkage of piped water with other sanitary techniques (e.g. baths, showers and washing bowls). Piped water linked up with the culture of cleanliness, facilitating more washing and scrubbing. Piped water was also used for water closets that experienced rapid diffusion in the 1890s. For rich citizens, health was not an important reason to adopt piped water. They already had clean drinking water, from private pumps or imported sources. Another early user group was industrial firms with particular needs for clean water (e.g. paper factories, beer breweries). For instance, in the city of Tilburg, piped waterworks were primarily created for the textile industry. In its first year of operation, about $91 \%$ of Tilburg's piped water was used by industry and $9 \%$ by local residents [35, p. 131]. Local residents could thus piggyback on industrial water demand. Another industrial use of water was the production of steam for steam engines. Polluted water might cause deposits on the boilers, reducing their efficiency [34, p. 27]. Other early users were municipal agencies, e.g., fire department, 
cleaning departments (wetting the streets to diminish dust problems, flushing out public urinals).

This analysis of motivations of relevant social groups shows that hygienic considerations about clean drinking water were not crucial for the take-off of piped water systems. If there was a direct link with hygiene, it was mainly through washing, cleanliness and personal hygiene. The norm of cleanliness acquired new meaning as the insights of new medical theories penetrated society. While cleanliness was previously linked to social distinction, it acquired the additional association with health and disease. The linkage between 'dirtiness' and disease reinforced the repulsion and fear that middleclasses had for the working classes. Especially the notion of the ever-present but invisible 'microbe', central in new medical theories, reinforced these fears. 'The microbe materialised the risk and identified it. Hence, the new role for cleanliness: fighting against enemies now quantifiable.... However, this multiform being, polluting on coloured plates, totally escaped the naked eye. The consequences were inevitable: to wash was, as never before, to operate on the invisible [48, p. 203].' The hygienist doctors sometimes dramatised the new insights and indicted a fear of infection with their suggestive rhetoric of 'armies of microbes' that were always ready to cross the body's frontiers. From then on, bodies had to be scrubbed and washed extensively with soap, while disinfection of clothes became the central element in laundering [54, p. 120]. Cleanliness practices had to combat an invisible but omnipresent enemy. To be a good and healthy family, meant being clean and fresh.

The medico-scientific prescriptions about cleanliness norms were eagerly taken up by the middle classes. They fitted perfectly in the existing morality of family, propriety, control and cleanliness. Medical scientific insights even gave these existing norms additional legitimation and power, forming the background of an ideology of cleanliness.

The diffusion of piped water linked up with these changing ideas about cleanliness and personal hygiene, and greatly reinforced them. Piped water stimulated the diffusion of showers and baths in upper- and middle-class households on a wider scale. For those that could not yet afford private baths and showers, public bathing houses were set up in the 1880s. In 1886, a bathhouse was opened for the middle-classes in Maastricht, containing 12 rooms with bathtubs, and 6 with showers [34, p. 75]. Until 1900, its popularity increased. But as the middle-classes purchased private washing facilities, numbers began to drop. The bathing culture also began to spread to the working classes, as indicated by the display of a working class bathing house at the international hygiene exhibition in Berlin in 1883 [52, p. 62]. This consisted of a simple iron shed with ten showers. The emergence of a bathing culture stimulated the use of soap on a massive scale. Soap companies stimulated new cleanliness norms in their advertising $[55,56]$. Taxes on soap gradually disappeared, lowering its price. In Britain, the tax on soap was already abolished in 1852, in the Netherlands in 1893 [57].

\subsection{Diffusion of piped water and the emergence of a hygiene ideology (1900-1930)}

\subsubsection{Landscape developments}

An important macro-cultural change was increased sensitivity for the condition of the working classes and the social issue. This contributed to more intervention from public 
authorities in society. At the national level, intervention mainly occurred in the form of regulations providing more protection for workers and their families (e.g. the Safety Law (1895), new Labour Law (1899), Social Insurance Laws (1900)). In 1901, a new Housing Law formulated some minimal requirements for the conditions of newly built houses (e.g. sufficient access to clean drinking water). Also in 1901, a new Health Care Law gave local health commissions more power to supervise if the requirements in the Housing Law were met $[47$, p. 80]. Another response to the social issue was the so-called civilisation offensive $[58,59]$, spearheaded by middle-class reform movements. The prevalent idea was that working classes were poor, because of deficiencies in character and behaviour. Hence, help to working class families took the form of teaching them new norms and civilised behaviour. Working class families had to be educated and disciplined, through the transfer of middle-class values and routines. This civilisation offensive was reinforced through several social mechanisms. For instance, housing associations employed supervisors to make regular visits to families, inspecting to see if they were homely, clean, thrifty, and diligent [58]. Poor care organisations also visited working class families. They not only handed out money and support, but also checked to verify if the money was well spent and tried to educate working class people into independent citizens. Churches also interfered and religious charities visited families, giving them advice about good morals regarding housekeeping, child raising, etc. Schools also became an important means to teach children new practices and knowledge about hygiene [40, p. 101]. This involved hygienic life rules that are now common practice, e.g. cover your mouth when coughing or sneezing, have a varied and regular diet, brush your teeth before sleeping [49]. The late 19 th and early 20th century also saw changes in the role of women in the nuclear family. With industrialisation, a new distribution of roles emerged between men and women. Dutch society became more domestic. Men worked in factories to earn money, and women stayed at home to do the household. Care was increasingly defined as a female task, with hygiene forming an important aspect. The nuclear family became a new cultural ideal, involving more care for children, and proper, clean households.

\subsubsection{Regime developments in drinking water and personal hygiene}

By 1900 , around $40 \%$ of the Dutch population was connected to piped water. By 1951, the percentage had risen to $82.4 \%$ [38, p. 7]. In rural areas this percentage was much lower (Table 3).

Middle-class families were quick to shift to piped water, because it offered more comfort and cleanliness. As piped water diffused in the middle-class household, a new 'water culture' emerged, centered around new user practices and new technical objects

Table 3

Percentage of population in Dutch provinces connected to piped waterworks in 1951 [38, p. 7]

\begin{tabular}{llll}
\hline Groningen & $72.4 \%$ & North-Holland & $98.6 \%$ \\
Friesland & $59.6 \%$ & South-Holland & $97.8 \%$ \\
Drente & $37.3 \%$ & Zeeland & $80.6 \%$ \\
Overijssel & $75.5 \%$ & North-Brabant & $76.1 \%$ \\
Gelderland & $59.7 \%$ & Limburg & $72.3 \%$ \\
Utrecht & $92.7 \%$ & & \\
\hline
\end{tabular}


Table 4

Sanitary objects in Maastricht households [34, p. 88]

\begin{tabular}{llll}
\hline & Baths & Water closets & Number of connected houses \\
\hline 1898 & 106 & 429 & $? ?$ \\
1900 & 133 & 551 & 1966 \\
1906 & 180 & 1178 & 2939 \\
1921 & 412 & 3875 & 5599 \\
\hline
\end{tabular}

such as water closets, baths, showers, washbasins, and washing machines. The number of these hygienic objects increased rapidly (see Table 4). Water closets were usually more popular than baths and showers [60]. For working classes the use of sanitary products was limited. Their primary use of piped water was drinking, cooking, washing of clothes, and sometimes water closets. Baths and showers long remained a luxury for the middle-class [52, p. 79].

The diffusion of piped water and hygienic products was accompanied by the articulation of new user practices. More people began to bathe and wash at home. Washing machines entered rich households. And users applied water for many other purposes: wetting streets (to diminish dust problems on unpaved roads), removing dirt and snow from pavements, and cleaning windows (Fig. 9).

As a new water culture emerged, water consumption per person increased rapidly (Fig. 10). The rapidly growing water use created problems for water companies, because their water-win sites had not been designed for such amounts. Hence, water companies tried to limit the use of water. In Rotterdam there was a public campaign against too much private use of piped water [33, p. 43]. In Maastricht, water companies issued regulations in the 1910s to prohibit users to sell or give water to others [34, p. 50]. Between April and September it was forbidden in Maastricht to wet the streets other than by hand and bucket. Before World War I an important topic was the articulation of proper user routines for domestic servants. They should limit the use of water hoses to clean pavements and facades [33, p. 44].

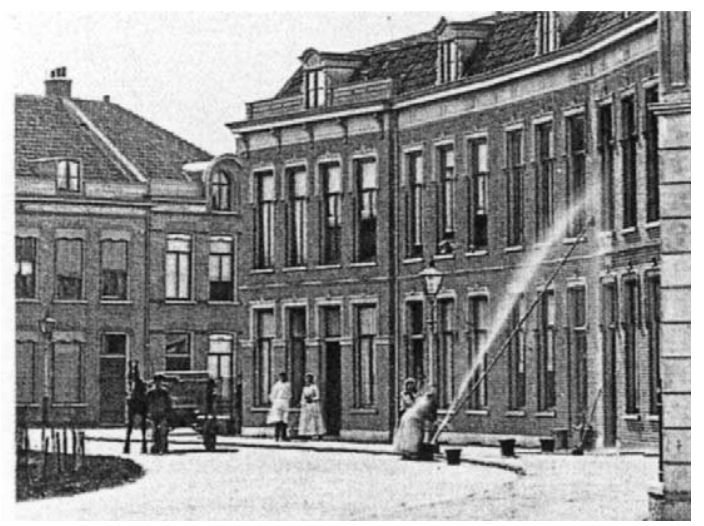

Fig. 9. Domestic servants clean houses in Haarlem, around 1890 [47, p. 71]. 


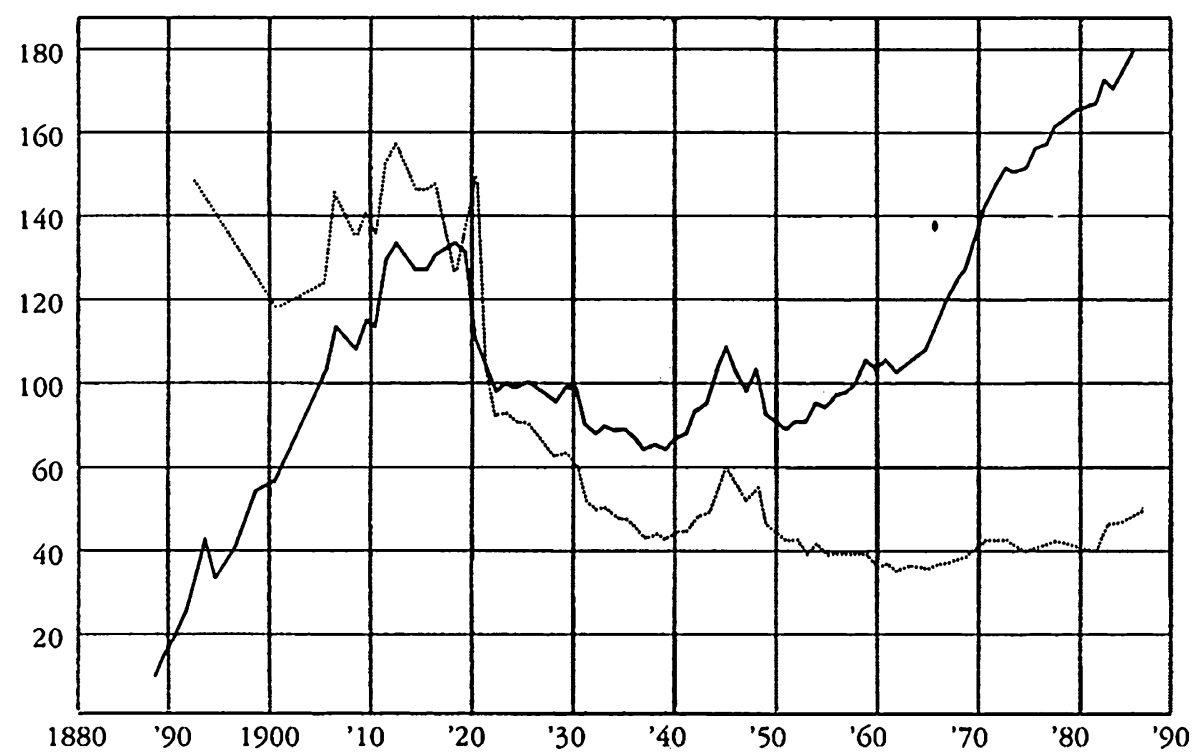

Fig. 10. Private water consumption in Maastricht, per house (grey line) and per person (dark line) in liters/day [34, p. 161].

At the supply-side of piped water, there were many technical learning processes, leading to the articulation of quality norms and a new technological regime. The emergence of a new technical community was signalled by the creation of the Dutch water association, VWN, in 1899. VWN lobbied for the interests of the water industry, and disseminated knowledge to its members, organised meetings, exchanged experiences, etc. In the early 20th century, the national government was hardly involved in water supply matters, leaving much space for self-regulation regarding definitions of the quality of good water. Early definitions were mainly qualitative, involving turbidity, colour, visible contamination and taste. In the 1880s, definitions were based on chemical knowledge about levels of calcium, iron and lead. Ground water frequently had too high concentrations of calcium and iron, making the water 'hard' and influencing its taste. Lead contamination could occur, because cast iron pipes were sometimes caulked by lead, or in-house pipes were made from lead which was cheaper than copper [61, p. 11]. But the findings from Koch and Pasteur opened up a whole new body of knowledge: microbiology. Because microbiological knowledge was not immediately stabilised in a scientific paradigm, it was difficult to formulate standards for bacteriological purity. German authorities defined an arbitrary standard for bacteriological purity in 1895: 100 bacilli per cc. In the Netherlands, the Dutch Congress for Public Health published a Codex in 1904, providing indications for chemical and microbiological analyses [61, p. 4]. In 1909 VWN developed water quality norms that were indicative, not prescriptive. Formal norms were not articulated until 1957, when a national Piped Water Law formally stated the chemical and biological requirements of drinking water. The lack of formal norms in the early 20th century was related to the weak development of testing and quality control. 
A survey by the Central Health Committee in 1908 showed that many waterworks did not monitor water quality at all, others sporadically, and a few regularly [61, p. 18]. In Amsterdam, for instance, the laboratory for water analysis did not use regular biological analysis until 1917 [61, p. 18].

Another supply-side issue was water purification to make water safe for drinking. Especially surface water was a problematic source, because it was often contaminated with bacteria, organic material or chemical pollution from factories. Although a range of water purification methods were developed in the 19th century, waterworks implemented them in varying degrees, since stringent norms and policing were lacking. A simple way to remove dissolved matter was sedimentation by allowing water to stand still for a couple of days. Most waterworks implemented this method, because it was simple and had obvious effects on the clarity of water. For ground water with high concentrations of iron, water companies constructed de-ferrification towers with coal beds. Another option in the purification process was the use of filters to remove impurities from surface water. Sand filters were first developed in the United Kingdom in 1828 by James Simpson [62, p. 276]. To secure enough contact with oxygen, water was sprayed over large filter beds, consisting of layers of sand and graded gravel. This was a slow process, working at a speed of $0.10 \mathrm{~m} / \mathrm{h}[63$, p. 63]. As the quantities of drinking water increased, the low speed meant that ever-larger surfaces were needed for filtering. Hence, rapid sand filters were developed in the United Kingdom in the 1870s, applying pressure to force water through the sand layer in a metal container. But these rapid sand filters were less effective in removing germs [62, p. 276]. Nevertheless, slow and rapid sand filters were commonly used in the Netherlands, although not all waterworks implemented them. In the early 20th century, there was also attention for alternative purification technologies, especially chemical disinfection methods, using agents like chlorine, potassium permanganate or ozone. Several ozone installations were tried in practice (e.g. in Breda, Rotterdam, Weesp) and found to be technically effective. But it was expensive, and hence not adopted on a large scale. Chlorination was also tested, (e.g. in Middelkerke, Belgium in 1902) but not widely applied before the 1930s [61, p. 13]. So water purification remained weakly developed, partly, of course, because there were no stringent norms regarding water quality.

Another reaction to the pollution of surface water was a gradual switch from surface water to ground water, especially dune water and aquifers, underground reservoirs which rested on impermeable soil/clay or rock. In 1898 about $50 \%$ of the total quantity of Dutch piped water was won from surface waters. In 1939 this percentage had dropped to $26 \%$ [52, p. 79].

The national government only slowly became involved in water supply matters. The first action was the creation in 1910 of a State Commission for the Question of the Supply of Drinking Water [47, p. 85]. In 1913 this Commission was split into two bodies: (a) the Central Commission Water Supply, which functioned as an advisory committee to policy makers, and (b) a State Office for Water Supply, which became a technical consultancy agency. The State Office did technical and scientific research, and set up a central chemical-bacteriological Water Laboratory in 1913 to analyse water samples. The State Office also turned into a product champion, advocating the spread of piped water to rural areas. 
The diffusion of piped water, water closets, baths, showers, washbasins, and washing machines linked up with the cultural desire for cleanliness and hygiene [64]. A hygienic ideology emerged as middle-class norms about cleanliness linked up with medical science. Cleanliness was not only important for social distinction, but also for health and hygiene. Hence, there was much public attention for personal care and hygiene, something that was reinforced by companies for whom this formed a growth market. The market for hygienic products included soap, shampoo, synthetic detergents, perfume, toothbrush and toothpaste, etc. Soap companies, for instance, eagerly advocated the new norms of cleanliness. Proper, healthy and clean behaviour was also advocated in a stream of brochures and journals. Leaflets were distributed that portrayed the new routines for washing of bodies, cutlery or clothes, coughing, sneezing and spitting (Fig. 11). Many of these new rules and routines form the roots of our present health and body culture [65].

The hygienic ideology provided a legitimate symbolic framework to justify the attempts to discipline and civilise the working classes [54, p. 122]. Hygiene and public health campaigns were used for hygienic and social disciplining of the urban masses. New health rules were imprinted on the working population by means of consciousness-raising channels. Important channels were schools, which increasingly gave attention to hygienic practices. Teachers required that pupils came to class clean and neat, and they made school showers available. The popularised press also undertook a major effort through printing and distributing popular brochures, health booklets, and magazines in which all kinds of tips and advice were given. Clubs and associations organised lectures to convince the population of the scientific necessity of a clean way of life.

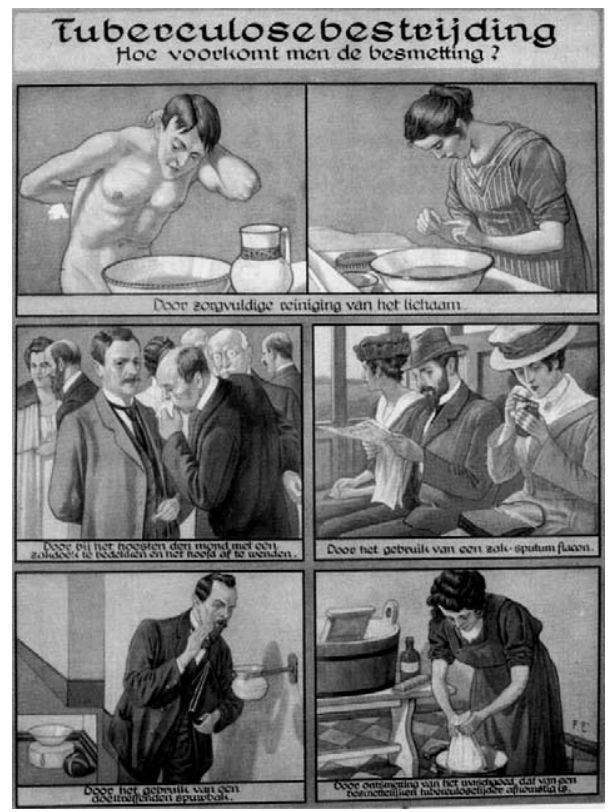

Fig. 11. Leaflets advocating hygienic practices in the battle against tuberculosis [47, p. 66]. 
Another crucial channel for spreading the new norms of health and hygiene was the education of the housewife. For the housewife was the 'guardian' of cleanliness and domesticity, of physical and moral health in the family. Between 1890 and 1920, numerous female professions in the pedagogical and care domain entered the 'civilizing' stage. Nurses, midwives, home inspectors, social workers, teachers, all of them played an important intermediary role in the actual transmission of hygienic norms to lower-class women [66, p. 167]. These new female professionals not only stressed health benefits, but also the moral value of neatness and cleanliness [67]. To train working class women, new schools were set-up, so-called domestic science education. One of the objectives was to teach the wives of workers how they, with a minimum of resources, could maintain the modern standards of hygiene and propriety. All these activities helped to spread the modern vision about households and cleanliness among workers and farmers families.

The health and hygiene campaigns had strength because they were backed up by medical science and were linked to the wider 'civilization offensive' [66]. Nevertheless, these campaigns were not immediately effective. 'Unhealthiness' and 'irregular ways of life' continued to predominate among the working classes for a long time. Scientific hygienic prescriptions often clashed with traditional popular wisdom, such as the idea that a layer of dirt formed a buffer against disease, and that multiple washing wore out clothing [54, p. 131]. Working class families often saw the hygienic demands and civilisation activities as humiliating interference in their daily life. The civilisation activities also frequently ran aground against limited financial resources of working class families, and limited access to sanitary facilities (water, toilet, bath, shower, etc.). The diffusion of piped water to working classes, for instance, was slow, because they did not have the money to afford connections.

There were three drivers that gradually stimulated working class families towards piped water. The first driver was cultural pressure from the hygienic and civilisation campaigns, backed up by social pressure from home inspectors, social workers, etc. The second driver was public policy from public authorities. Several policy actions created pressure. One action was that city governments reduced maintenance of public pumps, closing them down when their performance was very bad. In Maastricht, for instance, the creation of a piped water system gave the city government an additional reason to downscale their responsibility for public pumps [34, p. 93]. As a result, the public water supply system rapidly deteriorated, pushing families towards piped water. Another kind of action was that city governments declared private pumps unfit, appealing to public health regulations that they usually neglected. Also, city governments sometimes deliberately polluted surface waters to prevent citizens from drinking it. The city of Breda, for instance, added petroleum to the canals in 1892 to prevent the spread of cholera [68, p. 14]. National governments also created pressure, e.g. through the Housing Law (1901) that articulated quantitative norms about the presence of safe drinking water on housing premises and about the maximum distance to a good water source. Although these national regulations provided a basic framework, it was left to city governments to implement them in practice, something they often did in an opportunistic way. Another driver that stimulated working classes towards piped water was a gradual decrease in the price of piped water. This was possible because water companies benefited from economies of scale in the early 

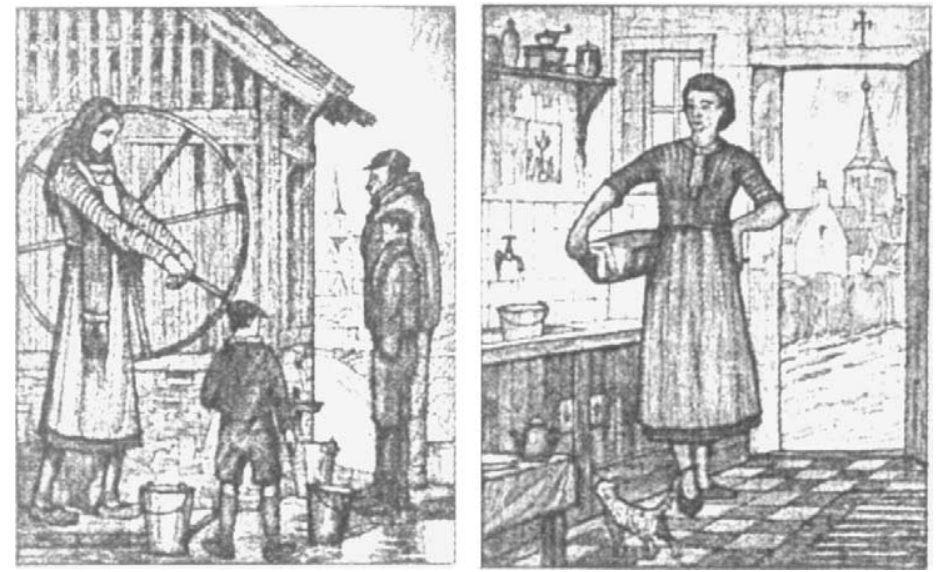

Fig. 12. Advertisement from the Limburg water company in 1930 contrasting the hard work of water pumping with the ease of piped water [47, p. 76].

20th century. Water prices in Maastricht decreased from 19 cents per cubic meter 1893 to 10 cents in 1920 [34, p. 160].

Rural areas were slow to shift to piped water. Hence, propaganda campaigns for rural areas were designed and implemented in the 1920s and 1930s. Films and leaflets contrasted the hard work involved in pumping water outdoors with the ease of 'modern' piped waterworks (see Fig. 12). But it was not easy to convince farmers that piped water was better than traditional water sources. Furthermore, water companies would not be profitable in rural areas, because large distances had to be covered to connect remote residents, involving high costs. The national government stimulated the spread of piped water in rural areas with financial subsidies to local water companies, helping to overcome initial financial barriers. Although waterworks gradually entered rural areas, rural areas often continued to rely on traditional water sources until after World War II.

\section{Analysis and discussion}

This section distills some of the main features of co-evolution of technology and society in this transition. It is important to note that the main difficulty with piped water was not the development of technology. Steam engines, pumps, piped and watertowers had already been developed in other countries and posed no major technical problems. The problem was that these components needed to be combined in a large technical system. This meant it could not be implemented in a piecemeal fashion, step-by-step. A threshold had to be overcome to create an infrastructural network that could serve customers. The case study showed that this threshold was lowered by keeping the initial distribution network in cities limited. Rich citizens with subscriptions would have the pipe infrastructure extended to their houses. But the other distribution method was to sell water per bucket via taps connected to a main waterpipe. So, initially, not all users had piped water in their houses, but would still collect water at public points. By keeping 
the urban distribution network limited, the initial threshold was lowered. But still, this threshold meant that a large sum of money was needed up-front, to dig wells, lay pipes, create a watertowers, etc. The main problem was financial (how to find investors) and economic (would there be sufficient demand from customers with buying power).

These considerations mean that the influence from society on technology was less on development of technology and more on implementation, adoption and diffusion. The case study showed that there were some early niches for piped water in the 1850s, depending mainly on local, contingent factors (scarcity in Amsterdam, and ships in Den Helder). There was some expansion of piped water in the mid-1870s, but the take-off took place in the mid-1880s and -1890s. Several societal developments were important for the take-off. To overcome the initial threshold, the crucial variable was the (expected) size of users willing and able to pay for piped water. This variable was influenced by two external landscape developments: (a) economic growth, which accelerated as industrialisation gathered speed; hence, there were more people with money to spend, (b) urbanisation and the growth of cities; this meant that more people might be serviced with the same infrastructure; especially the creation of new urban neighborhoods for the middle-class provided a suitable space for piped water systems (since it did not require existing infrastructures to be broken up). The crucial variable was also influenced by ongoing cultural developments. Cleanliness had already become an important cultural norm for the middle-class in the 1860 s and 1870 s, not so much for health reasons, but for social distinction between classes. This cultural norm was accompanied by changes in bathing and washing practices (e.g. bathing houses, increased use of soap). There were some private baths, showers and water toilets, but their water reservoirs were filled by hand by servants. Since piped water would greatly facilitate the use of these hygienic objects, there was increased willingness to pay for it. Piped water thus linked up with an ongoing change in the cultural meaning of cleanliness, and associated washing and bathing practices. Cleanliness acquired an additional cultural meaning in the 1880s and 1890s, when new insights from medical science entered society. Through micro-organisms, filthiness was linked with disease. So cleanliness acquired additional importance with regard to health, strengthening the desire for hygienic objects and the willingness to pay for piped water. A landscape development that also stimulated the take-off of piped water, was the change in political culture, in particular the increased willingness by public authorities to intervene in society. This change in role-perception was, in turn, related to increased sensitivity for the social issue, the emergence of new political parties, and an erosion of the liberal ideology. The change in political culture meant that city governments in the $1890 \mathrm{~s}$ increasingly took responsibility to set up piped water systems themselves, without waiting for private initiative.

There was also a very strong influence from society on the diffusion of piped water and hygienic practices to the working classes, in the early 20th century. The case study showed there was a major societal effort from the middle-classes to educate and 'civilize' the working classes, to transfer their own middle-class norms. The civilisation offensive was a cultural development, backed up by many social groups (e.g. midwives, home inspectors, social workers, teachers), and using a range of social mechanisms (e.g. school, media, leaflets, house visits). Hygiene and health campaigns linked up with this wider development, trying to teach the working classes new rules for health and personal 
care. Regular washing of clothes, bodies, hair and teeth were part of the new routines, and they depended crucially on clean water. So the civilisation offensive and hygiene campaigns were important to stimulate the wider diffusion of piped water. Working classes were also pushed towards piped water by public authorities, policies and regulations. Public authorities made the use of traditional water supply sources more difficult and issued housing regulations that stimulated piped water. So, culture and policy were both important drivers for the diffusion of piped water and personal care.

On the other hand, science and technology also influenced society. For instance, medical science in the 1840s and 1850s first articulated linkages between unhygienic conditions and disease. In particular, hygienist doctors placed the problem of polluted drinking water on the societal agenda, leading to discussions in city councils, newspapers, etc. In the $1880 \mathrm{~s}$, new medical theories about micro-organisms led to a new hygienic problem articulation: armies of microbes were everywhere to invade the body. This more general problem articulation created a link between health and personal hygiene and care. This scientific view had much influence on society, because it linked up well with the existing cleanliness culture and middle-class norms. The medical insights were used as scientific legitimation for a moral and cultural crusade (the civilisation offensive and hygiene campaigns). In retrospect, this had some good effects in terms of health. But, there was also a degree of misuse, in the sense that science was used to push through other, nonhygienic, middle-class norms. Technology also had other influences on society. The rise of piped water was a catalyst that stimulated the diffusion of a range of hygienic products, such as water closets, baths, showers, washing machines, washing bowls. Although these products already existed before piped water, their market share was greatly stimulated by piped water. Through these products, piped water was a crucial element in the emergence of a new hygienic culture, with new practices around washing, bathing, etc. A cleanliness culture already existed before piped water, but it was spread and transformed into a hygienic culture through piped water. Piped water also gave rise to a new sector around water-supply, giving rise to new social groups (water companies and their branch organisation), new knowledge and laboratories, new government offices and responsibilities, new regulations and norms, new technologies (e.g. for purification and disinfection).

So the conclusion is that there was substantial co-evolution between technology and society in the transition towards piped water and personal hygiene. An additional point for discussion is whether this transition was a rational goal-oriented process, following three phases: problem articulation, search for solutions, implementation of solution. At first sight, it might seem that the transition followed these phases. Hygienist doctors articulated the problem about polluted drinking water and disease in the 1840s and 1850s. The $1860 \mathrm{~s}$ and 1870s saw discussion and some implementation of piped water systems. And then wide implementation followed in the 1880s and 1890s. But such a characterisation of this transition is misleading, suggesting too much linear rationality. I agree with the first phase of problem articulation, placing relationships between disease and polluted drinking water on the agenda. But in the 1860s and 1870s, societal concerns and debates about this problem had little direct effect. They did not stimulate city governments to take substantial action. City governments preferred inexpensive, incremental solutions within the existing regime (e.g. create some more pumps, or improve water circulation in canals, using steam 
engines and pumps). In the 1880s and 1890s, there were two hygienic problems: (a) polluted drinking water and (b) general concerns about micro-organisms, hygiene and health, leading to a culture of cleanliness, and a desire for washing, scrubbing, cleaning and flushing. The take-off of piped water in the 1880s and 1890s was related not to the first, but to the second problem. So there is no direct link between the problem, first signalled in the 1840 s and 1850s, and the solution of piped water. Piped water was implemented, because it became linked to another problem that had wide societal attraction, because it linked up with middle-class norms. Furthermore, the implementation of piped water in the 1880 s and 1890 s was related to broader societal developments as described earlier in this section. The analysis of the motivations of relevant social groups (Section 3.3) also showed that health problems related to drinking water were not very important for their adoption decision. Considerations related to economy and profits, prestige (both for cities and users), comfort, and cleanliness were more important than healthy drinking water. In sum, the transition was not a rational goal-oriented process meant to solve drinking water problems. Instead, it was non-linear, depending much on external developments and changing linkages between problems and solutions.

\section{Conclusions}

With regard to Freeman and Perez's innovation typology, little attention has been paid, so far, to system innovations. At this level, changes do not only involve radical technical innovations, but changes in socio-technical systems. Transitions at this level should not only be studied as technological discontinuities, but also as co-evolution of technology and society. This article proposed that the multi-level perspective (MLP) was a good framework to study transitions at this level. Earlier case studies have shown that the MLP was suitable to study technological transitions (i.e. system innovations with a strong technological component). The case study in this article has shown that the MLP is also useful to understand transitions with important cultural and societal aspects. Because the application of the MLP to the co-evolution of technology and society was successful, the conclusion is that the MLP is robust and widely applicable.

In this particular case study, the interaction between the different levels was as follows. By the middle of the 19th century, problems in the water supply regime grew worse, as increasing urban populations dumped their waste in canals and surface waters. Local conditions in some specific cities provided space for the first piped water systems in the 1850s. But this niche did not further diffuse. Problems in the water supply regime grew worse in the 1860s and 1870s, but public authorities did not embrace the niche. Instead, they searched for solutions within the existing regime. Only after wider landscape developments in the 1880s and 1890s (economic, cultural, political) could the niche break through and trigger wider transformations. So external macro-developments played a crucial role in the take-off and diffusion phase of this transition. A suggestion for further research is to investigate the precise interactions between the three levels in other case studies. My expectation is that different kinds and sequences of interaction may lead to different routes in transition processes. 


\section{References}

[1] Coombs R, Green K, Richards A, Walsh V. Technology and the market: demand, users and innovation. Cheltenham, UK: Edward Elgar; 2001.

[2] Lundvall BA. Innovation as an interactive process: from user-producer interaction to the national system of innovation. In: Dosi G, Freeman C, Nelson R, Silverberg G, Soete L, editors. Technical change and economic theory. London: Pinter; 1988. p. 349-69.

[3] Clark KB. The interaction of design hierarchies and market concepts in technological evolution. Res Policy 1985;14:235-51.

[4] Leonard-Barton D. Implementation as mutual adaptation of technology and organisation. Res Policy 1988; 17:251-67.

[5] Oudshoorn N, Pinch T. How users matter: the co-construction of users and technology. Cambridge, Massachusetts: MIT Press; 2003.

[6] Nelson RR. The co-evolution of technology, industrial structure, and supporting institutions. Ind Corp Change 1994;3(1):47-63.

[7] Van de Ven AH, Garud R. The co-evolution of technical and institutional events in the development of an innovation. In: Baum JA, Singh JV, editors. Evolutionary dynamics of organizations. New York, Oxford: Oxford University Press; 1994. p. 425-43.

[8] Rosenkopf L, Tushman M. The co-evolution of technology and organization. In: Baum J, Singh J, editors. Evolutionary dynamics of organizations. Oxford: Oxford University Press; 1994. p. 403-24.

[9] Leydesdorff L, Etzkowitz H. The tripple helix as a model for innovation studies. Sci Public Policy 1998; 25(3):195-203.

[10] Leydesdorff L. The triple helix: an evolutionary model of innovations. Res Policy 2000;29:243-55.

[11] Callon M, Laredo P, Rabeharisoa V. The management and evaluation of technological programs and the dynamics of techno-economic networks: the case of the AFME. Res Policy 1992;21:215-36.

[12] Stankiewicz R. Technology as an autonomous socio-cognitive system. In: Grupp H, editor. Dynamics of science-based innovation. Berlin: Springer; 1992. p. 19-44.

[13] Kline SJ, Rosenberg N. An overview of innovation. In: Landau R, Rosenberg N, editors. The positive sum strategy: harnessing technology for economic growth. Washington, DC: National Academy Press; 1986. p. 275-305.

[14] Layton E. Mirror-image twins: the communities of science and technology in 19th century America. Technol Cult 1971;12(4):562-80.

[15] Layton E. American ideologies of science and engineering. Technol Cult 1976;17(4):688-701.

[16] Du Gay P, Hall S, Janes L, MacKay H, Negus K. Doing cultural studies: the story of the Sony Walkman. London: Sage Publications; 1997.

[17] Van Dijck J. Imagenation: popular images of genetics. New York: New York University Press; 1998.

[18] Freeman C, Perez C. Structural crisis of adjustment, business cycles and investment behaviour. In: Dosi G, Freeman C, Nelson R, Silverberg G, Soete L, editors. Technical change and economic theory. London: Pinter; 1988. p. 38-66.

[19] Fleck J. Configurations: crystallizing contingency. Int J Hum Fact Manuf 1993;3:15-36.

[20] Hughes TP. The evolution of large technological systems. In: Bijker WE, Hughes TP, Pinch T, editors. The social construction of technological systems: new directions in the sociology and history of technology. Cambridge, Massachusetts: The MIT Press; 1987. p. 51-82.

[21] Geels FW. From sectoral systems of innovation to socio-technical systems: insights about dynamics and change from sociology and institutional theory. Res Policy 2004;33(6/7):897-920.

[22] Geels FW. Technological transitions as evolutionary reconfiguration processes: a multi-level perspective and a case-study. Res Policy 2002;31(8/9):1257-74.

[23] Geels FW. Technological transitions and system innovations: a co-evolutionary and socio-technical analysis. Cheltenham: Edward Elgar; 2005.

[24] Kemp R. Technology and the transition to environmental sustainability. The problem of technological regime shifts. Futures 1994;26(10):1023-46.

[25] Schot J, Hoogma R, Elzen B. Strategies for shifting technological systems. The case of the automobile system. Futures 1994;26:1060-76. 
[26] Schot JW. The usefulness of evolutionary models for explaining Innovation. The case of the netherlands in the nineteenth century. Hist Technol 1998;14:173-200.

[27] Kemp R, Schot J, Hoogma R. Regime shifts to sustainability through processes of niche formation: the approach of strategic niche management. Technol Anal Strategic Manage 1998;10:175-96.

[28] Kemp R, Rip A, Schot J. Constructing transition paths through the manage-ment of niches. In: Garud R, Karnoe P, editors. Path dependence and creation. New Jersey: Lawrence Erlbaum Associates Publishers; 2001. p. 269-99.

[29] Hoogma R, Kemp R, Schot J. Experimenting for sustainable transport. The approach to strategic niche management. London and New York: Spoon Press; 2002.

[30] Nelson RR, Winter SG. An evolutionary theory of economic change. Cambridge: Bellknap Press; 1982.

[31] Rotmans J, Kemp R, Van Asselt M. More evolution than revolution: transition management in public policy. Foresight 2001;3(1):15-31.

[32] Groen JA. Een cent per emmer: Het Amsterdamse drinkwater door de eeuwen heen (A cent per bucket: Drinking water in Amsterdam throughout the centuries). Amsterdam: Gemeentewaterleidingen; 1980.

[33] Van den Noort J. Pion of pionier: Rotterdam-Gemeentelijke bedrijvigheid in de negentiende eeuw ('Pawn or pioneer: Rotterdam's urban activities in the nineteenth century'). PhD thesis, University Leiden (in Dutch). Rotterdam: Stichting PK; 1990.

[34] Cillekes C, Van den Boogard J, Gales BPA. Loop naar de pomp: Geschiedenis van de watervoorziening en de waterleiding in Maastricht (Pumping water: A history of water provision and waterworks in Maastricht). Stichting historische reeks Maastricht 1988.

[35] Van der Heijden CGWP. Kleurloos, reukloos en smaakloos drinkwater: de watervoorziening in Tilburg vanaf het einde van de negentiende eeuw (Colourless, odourless and tasteless drinking water: drinking water provision in Tilburg since the late 19th century). Tilburg: Stichting tot Behoud van Tilburg Cultuurgoed; 1995.

[36] Mackenbach JP. De Veren Van Icarus: Over De Achtergronden van Twee Eeuwen Epidemiologische Transities in Nederland (The feathers of Icarus: On the backgrounds of two centuries of epidemiological transition in the Netherlands). Utrecht: Bunge; 1992.

[37] De Jonge JA. De industrialisatie in Nederland tussen 1850 and 1914 (Industrialisation in the Netherlands between 1850 and 1914). PhD thesis. Scheltema and Holkema: Amsterdam; 1968.

[38] Vogelzang I. De drinkwatervoorziening van nederland voor de aanleg van de drinkwaterleidingen (Drinking water systems in the netherlands before the construction of piped water). PhD thesis. Utrecht: Rijksuniversiteit Utrecht; 1956.

[39] Houwaart E. Medische satistiek ('Medical statistics'). In: Lintsen HW, editor. Geschiedenis van de techniek in de negentiende eeuw. Zutphen: deel 3; 1993. p. 19-45.

[40] HartUtrecht PD. Utrecht en de cholera, 1831-1910 (Utrecht and the cholera, 1831-1910). Zutphen: Walburg Perss; 1990.

[41] Houwaart E. Professionalisering en staatsvorming (Professionalisation and state formation). In: Lintsen HW, editor. Geschiedenis van de techniek in de negentiende eeuw. Zutphen: deel 3; 1993. p. 81-92.

[42] Corbin A. The foul and the fragrant: odor and the social imagination. London: Picador; 1994.

[43] Musson AE. In: Enterprise in soap and chemicals: Joseph Crossfield and Sons limited, 1815. Manchester: Manchester University Press; 1965. p. 1965.

[44] Baudet H. En vertrouwde wereld: 100 Jaar innwatie in Nederleand (A familiar world: 100 years of innovation in the Netherlands). Amsterdam: Bert Bakker; 1986.

[45] Verdoorn JA. Volksgezondheid en sociale ontwikkeling: Beschouwingen over het gezondheidswezen te amsterdam in de $19^{\mathrm{e}}$ eeuw (Public health and social development: Consideratons about health care in amsterdam in the 19th century). Utrecht, Antwerpen: Aula; 1965.

[46] Houwaart E. De Hygiënisten: Artsen, staat en volksgezondheid in Nederland, 1840-1890 (The hygienists: Doctors, state and public health in the Netherlands, 1840-1890). PhD thesis. Groningen: Historische Uitgeverij Groningen; 1991.

[47] Wijmer S. Water om te drinken (Water for drinking). Rijswijk: Vereniging van Exploitanten van Waterleidingbedrijven in Nederland (VEWIN) 1992. 
[48] Vigarello G. Concepts of cleanliness: changing attitudes in France since the middle ages. Cambridge: Cambridge University Press; 1988.

[49] Van Daalen R. Tot behoud van de gezondheid: Leefregels en een sociaal programma op wetenschappelijke basis (For preservation of health: Living rules and a social programme with scientific grounding). Amsterdams Sociologisch Tijdschrift 1990;17(1):47-73.

[50] De Swaan A. Zorg en de staat: Welzijn, onderwijs en gezondheidzorg in europa en de Verenigde Staten in de nieuwe tijd (Care and state: welfare, education and health care in europe and the united states in the new time). Amsterdam: Bert Bakker; 1989.

[51] Roding J. Schoon en net: hygiëne in woning en Stad: De cultuurgeschiedenis van bad en toilet (Clean and tidy: hygiene in house and cities: a cultural history of bath and toilet). Den Haag: Sdu; 1986.

[52] Leeflang KWH. Ons drinkwater in de stroom van de tijd ('Our drinking water in the flow of time'). Rijswijk, Vereniging van Exploitanten van Waterleidingbedrijven in Nederland; 1974.

[53] Groote PD. Kapitaalvorming in infrastructuur in Nederland, 1800-1913 (Capital investment in infrastructure in the Netherlands, 1800-1913). PhD thesis, Groningen University. Capelle aan den IJssel: Labyrint; 1995.

[54] Meulders C. The struggle for cleanliness: a socio-historical analysis of the laundry process. Masters thesis, Katholic University of Leuven; 1992.

[55] Wilkie JS, Vinikas V. Soft soap, hard sell: American hygiene in an age of advertisement. J Soc Hist 1993; 27(2):383-4.

[56] Graham KA. Advertising in Britain. 1914-1880 Soap advertising and the socialization of cleanliness. $\mathrm{PhD}$ thesis, Temple University; 1993

[57] Van der Most F. Veranderingen in wasgewoonten en de introductie van synthetische wasmiddelen in Nederland, 1890-1970 (Changes in washing habits and the introduction of synthetic detergents in the Netherlands, 1890-1970). Research Report. The Netherlands: Twente University; 1998.

[58] De Regt AJ. Arbeidersgezinnen en beschavingsarbeid: Ontwikkelingen in Nederland, 1870-1940 een historisch-sociologische studie (Working class families and civilization activities: Developments in the Netherlands, 1870-1940; a historical-sociological study). Meppel: Boom, PhD Thesis, VU: Amsterdam; 1984

[59] Mitzman A. Het beschavingsoffensief: Mentaliteit, cultuur en psyche (The civilization offensive: mentality, culture and psyche). Amsterdams Sociologisch Tijdschrift 1986;13(2):179-223.

[60] Wright L. Clean and decent: the history of the bathroom and the WC. Cornwall: TJ Press; 1984.

[61] DaruRisky M. Risky business: piped drinking water in Dutch towns, 1880-1920 First Conference of the European association of urban historians: European cities and their people. Amsterdam: Internationaal Instituut voor Sociale Geschiedenis; 1992 pp. 4-7.

[62] Coley N. From sanitary reform to social welfare. In: Chant C, editor. Science, technology and everyday life, 1870-1950. London: Routledge in Association with The Open University (first published in 1989); 1990. p. 271-93.

[63] Jäger J. Locale drinkwatervoorzieningen (Local sources for drinking water). Rijksinstituut voor drinkwatervoorziening, Vijftig Jaar Drinkwater, 1913-1963. The Hague: Mouton and Company; 1963.

[64] Goubert JP. The conquest of water: the advent of health in the industrial age. Oxford: Polity Press; 1989.

[65] Velle K. Lichaam en hygiene: Naar de wortels van de huidige gezondheidscultuur (Body and hygiene: the roots of contemporary health culture). Gent-Leuven: Miat-Kritak; 1984.

[66] De Leeuw K. Hygiene en gezondheid als terrein van beschavingsoffensief: Regulering en Disciplinering in Nederland en Noord-Brabant 1880-1940 (Hygiene and health as domains of the civilization offensive: Regulation and discipline in the Netherlands and North-Brabant 1880-1940). Sociale Wetenschappen 1988; XXXI(3): 145-52.

[67] Boenink M. Vrouwe Hygieia en de zeven richtlijnen. Voedingsvoorlichting en moraal (Goddess Hygiene and the seven guidelines: food education and morality). Tijdschrift voor Gezondheid en Politiek 1990;8: 10.

[68] Groeneveld N. Afvalwaterzuiveringsinrichtingen (Waste water treatment facilities) Report. Zeist: Stichting Projectbureau Industrieel Erfgoed (PIE); 1994. 
Dr Frank Geels is a post-doctoral researcher at the Department of Technology Management at Eindhoven University of Technology, the Netherlands. His main research topics are technological transitions and system innovations. He studies this topic with a multi-disciplinary approach, using insights from sociology of technology, innovation studies, history of technology and evolutionary economics. The conceptual work is grounded in historical case studies on transitions in the past. He has also explored possible future transitions in transport and energy, using socio-technical scenarios as a new exploration methodology. 